\title{
Postcards from the outside: European- contact rock art imagery and occupation on the southern Arnhem Land plateau, Jawoyn lands
}

\author{
Robert Gunn, Bruno David, Ray Whear, Daniel James, \\ Fiona Petchey, Emilie Chalmin, Géraldine Castets, Bryce Barker, \\ Jean-Michel Geneste and Jean-Jacques Delannoy
}

\section{Introduction}

The northwestern region of the Arnhem Land plateau has long been relatively well-documented and is renowned worldwide for its wealth of rock art, including numerous paintings referencing items of material culture, people and events of contact between local Aboriginal peoples, Macassans, Chinese and Europeans (e.g. Chaloupka 1993:190-206; Edwards 1979:32; May et al. 2010, 2013; Mountford 1956:162, 179; Wesley 2013). Many of these contact motifs depict Macassan and 19th- to early 20th-century European ships (Chaloupka 1993:190-205; Taçon et al. 2010); some are of newly acquired artefacts, such as rifles, knives and Macassan kris, and horses (May et al. 2013; Wesley 2013); others depict events from the 1880 gold rush in Pine Creek to the west of the plateau (Chinese miners; e.g. Edwards 1979); still others show themes relating to the Second World War (aeroplanes, Darwin wharf; Chaloupka 1993).

By contrast, the southern half of the Arnhem Land plateau is relatively poorly known. In 2005, the Jawoyn Association began to promote the systematic recording of rock art within Jawoyn lands in central-western to southwestern Arnhem Land, at first through the Jawoyn Rock Art and Heritage Project (JRAHP, 2005-2012) (Gunn and Whear 2007), followed in 2010 by a program of archaeological excavation and rock art dating (e.g. David et al. 2011; Geneste et al. 2012). These studies have focused on the little-studied rock art sites of Jawoyn lands, mostly but not exclusively on the Arnhem Land plateau itself (Figure 9.1). Here, the rock paintings revealed a wide array of artistic conventions in many cases much akin to those of the better-known northwestern parts of Arnhem Land, although across Jawoyn lands only seven sites have yet been seen to contain imagery depicting identifiable European or Asian contact themes (see below). This paucity of Western-contact imagery is despite what has arguably been the most intensive, systematic rock art recording project yet undertaken anywhere in Arnhem Land, and the largest database of rock art sites for any single region within the Arnhem Land plateau (Table 9.1; Figure 9.2). 
This chapter explores this incongruity in the distribution of Western-contact motifs contrasting northwestern and southwestern Arnhem Land in relation to the rich corpus of other kinds of rock art on the plateau. We stress from the onset that while images of 'Western-contact art' derive from a wide variety of responses to outsider influences, and include imagery that employs conventions akin and often indistinguishable to those of the pre-Western contact period, in this chapter we restrict our discussion to images of introduced objects and demonstrably foreign peoples.

Table 9.1 European contact-period rock paintings in Jawoyn lands, southwestern Arnhem Land plateau.

\begin{tabular}{|c|c|c|c|c|c|}
\hline Motif type & Colour & $\begin{array}{l}\text { Size }(\mathrm{cm}) \\
\text { (length } \geq \text { width) }\end{array}$ & Jawoyn Site \# & Condition & Comment \\
\hline Boat 1 & White & $167 \geq 89$ & \multirow[t]{7}{*}{ ARN-088/6 } & Good & People on board (6) \\
\hline Boat 2 & White & $28 \geq 15$ & & Good & People on board (4 or 10$)$ \\
\hline Boat 3 & White & $28 \geq 25$ & & Fair & People on board (10) \\
\hline Boat 4 & White & $25 \geq 28$ & & Good & People on board (8) \\
\hline Boat 5 & Yellow + red & $65 \geq 23$ & & very poor & Dotted infill \\
\hline Boat 6 & White + red & C. $130 \geq 50$ & & Poor & People on board (2) \\
\hline Boat 7 & White & $27 \geq 26$ & & Good & With anchor line \\
\hline Person with hat & White & $31 \geq 9$ & ARN-107/3 & Fair & Top hat \\
\hline Person with rifle & White & $70 \geq 25$ & ARN-019/M & Good & Rifle? and army hat \\
\hline Horse with rider & Red & $54 \geq 51$ & ARN-087/1 & Fair & Plus reins, no saddle \\
\hline Horse & White + red + grey & $347 \geq 236$ & ARN-074/A & Very poor & Under X-ray fish \\
\hline Metal axe & White + purple & $26 \geq 14$ & \multirow[t]{2}{*}{ ARN-082/1 } & Poor & In X-ray style \\
\hline Metal hoe & White & $20 \geq 12$ & & Fair & Blades (?) (2) \\
\hline Steer & White & $67 \geq 46$ & ARN-031/1 & Good & With neck-bell \\
\hline
\end{tabular}

Source: Authors' data.

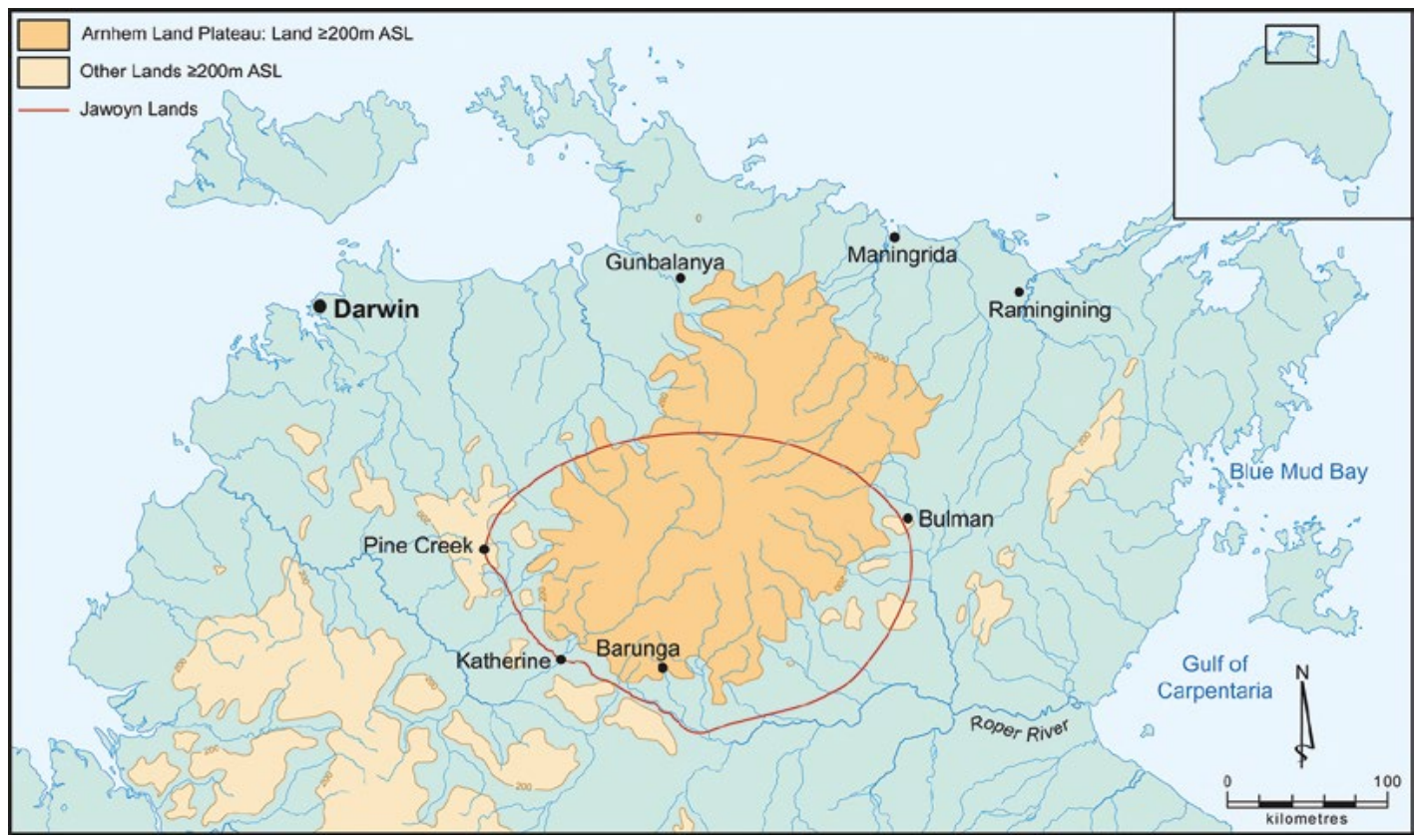

Figure 9.1 Location of Jawoyn lands.

Source: Kara Rasmanis. 


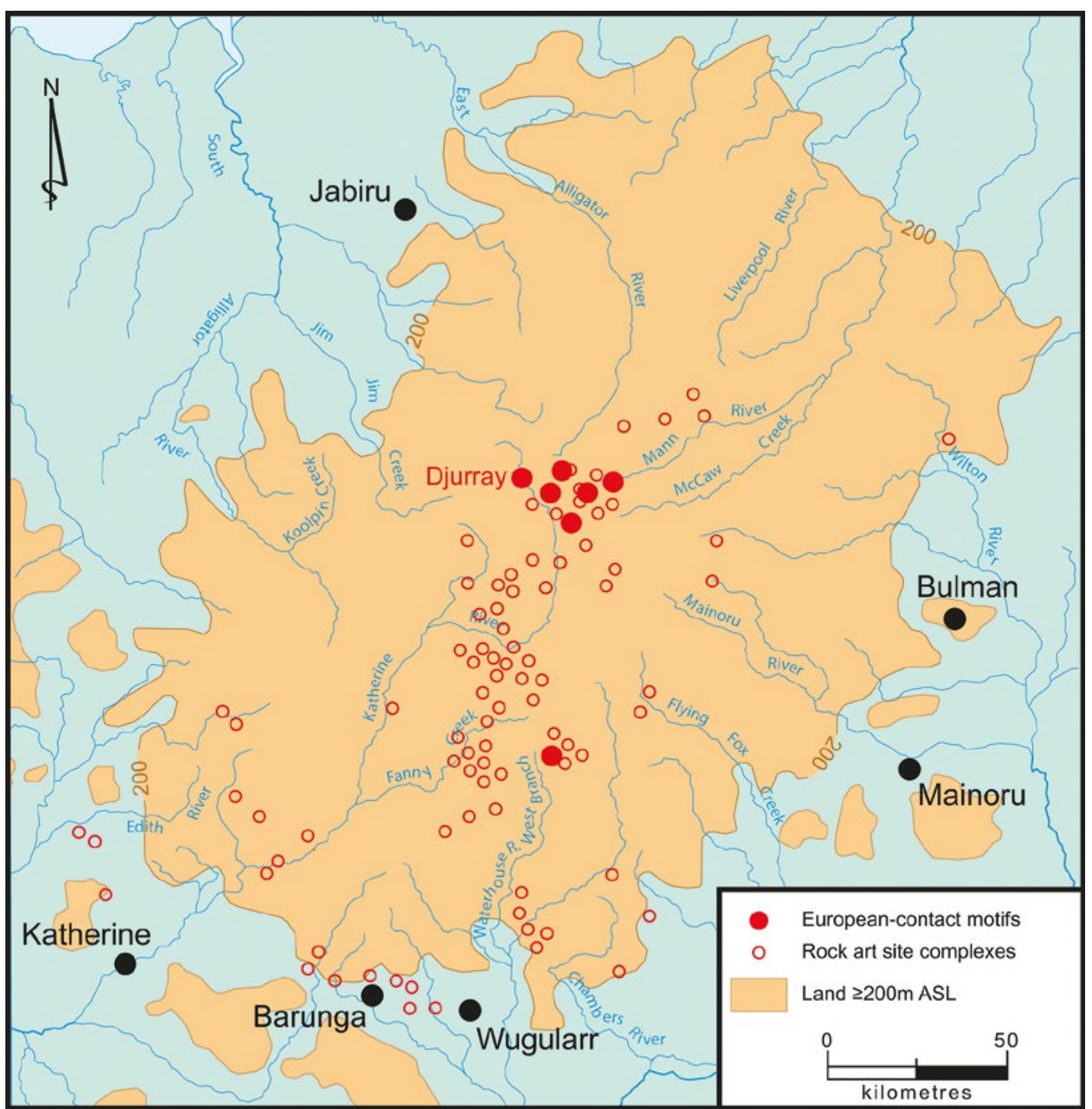

Figure 9.2 Distribution of rock art sites with European-contact motifs.

Source: Kara Rasmanis.

\section{Djurray: A major contact imagery site on the Arnhem Land plateau}

May et al. (2013:52) suggest that contact rock art need not be found only in the immediate area where cross-cultural meetings took place. Like traded objects, information regarding crosscultural encounters spreads quickly through wide-ranging social networks. People themselves commonly travelled across social boundaries, enabling new information to rapidly reach faraway places. Indeed the greatest number of demonstrably Western-contact images in Jawoyn lands occurs at Djurray (Jawoyn site ARN-088/6), a rock art site with maritime motifs some $150 \mathrm{~km}$ inland from the coast and separated from it by some of the most rugged terrain on the plateau and, more significantly, by lands that are not Jawoyn. The Djurray site is at the northern limit of Jawoyn lands, although its Jawoyn ownership is contested by an adjacent group. Margaret Katherine (pers. comm. 2011), the senior Jawoyn Traditional Owner for the lands immediately to the south, terms Djurray a 'shared site' between herself and her northern neighbours. 
The Djurray shelter is large, $23 \mathrm{~m}$ wide across its mouth, $6 \mathrm{~m}$ deep from overhang to back wall and $8 \mathrm{~m}$ high at the outer edge of the overhang. The shelter is open with a high rear wall that is extensively decorated with over 300 rock art images (both recent and older-looking paintings, stencils, prints and drawing), seven of which are depictions of European-contact objects (Table 9.1). The artwork at the shelter is dominated by a large white painting, Boat $\mathrm{A}$ ( $1.67 \mathrm{~m}$ long $\times 0.89 \mathrm{~m}$ high), with a crew of six wearing broad-brimmed European-style hats standing alongside square waist-high 'crates' (Figure 9.3). On the panel below the white boat are the three smaller Boats B-D, also in white, with hatless crews, triangular sails and steering oars (Figure 9.4). Below these again, there is Boat E, a three-masted vessel in yellow and red (Figure 9.5), in a relatively poor state of preservation caused by passing animals rubbing the pigment away. Two metres to the right of this group of images is Boat $\mathrm{F}$, also large and with a square sail and a crew of two (one wearing heeled boots), the ensemble of artworks painted in white and red with an unusual white-dotted infill (Figure 9.6). Boat $F$ is partially superimposed by Boat G, a small white sailing boat with a long rope line and anchor (Figure 9.6).

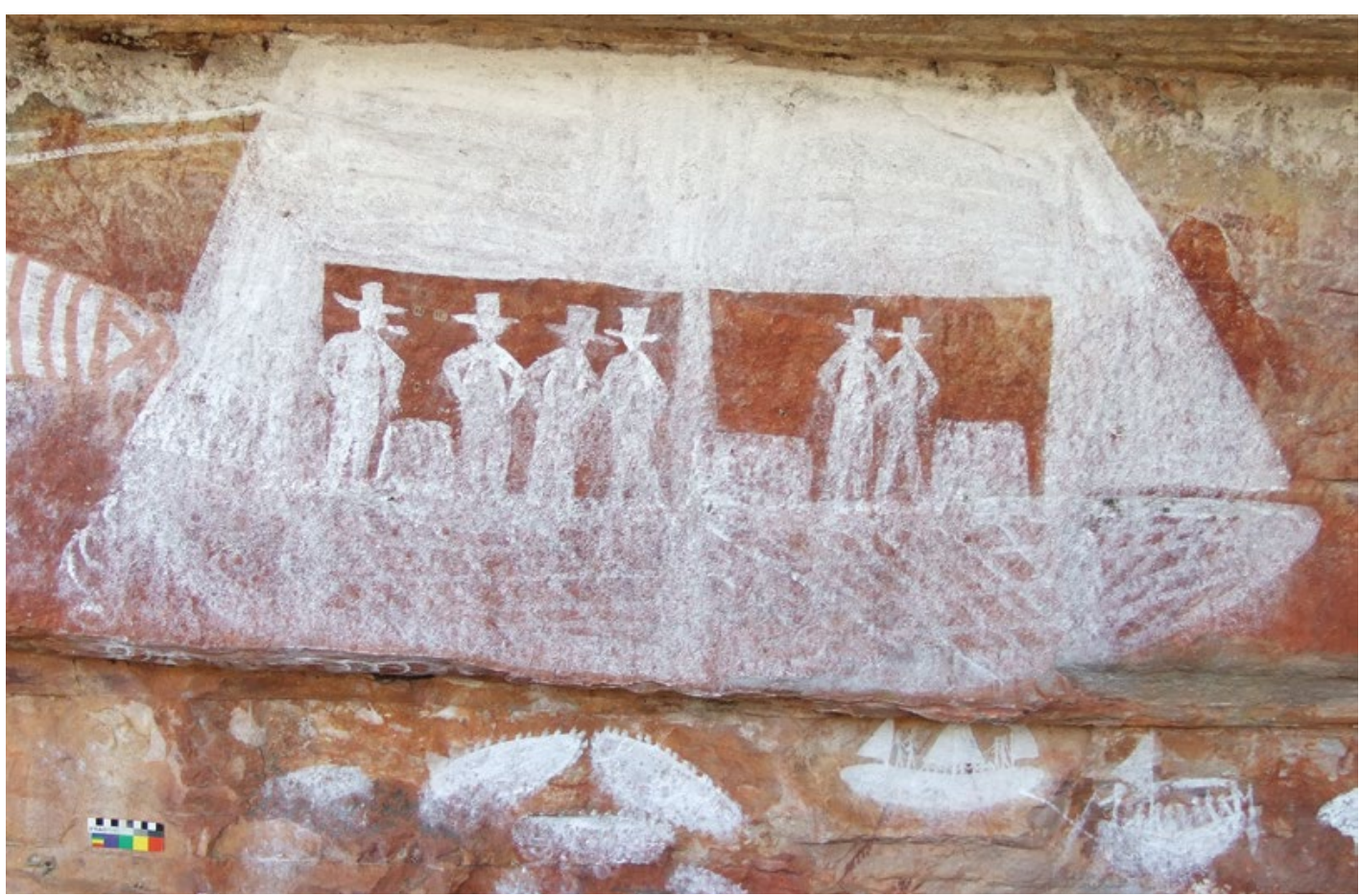

Figure 9.3 Boat A, site ARN-088/6. Scale $10 \mathrm{~cm}$.

Source: Photograph by Robert Gunn.

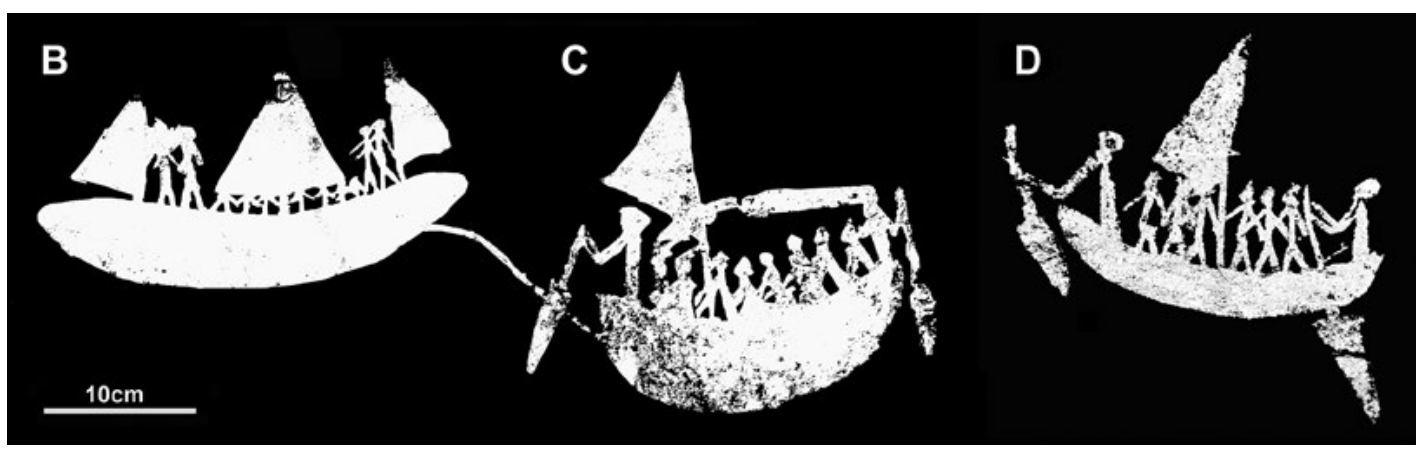

Figure 9.4 Boats B-D, site ARN-088/6.

Source: Robert Gunn. 

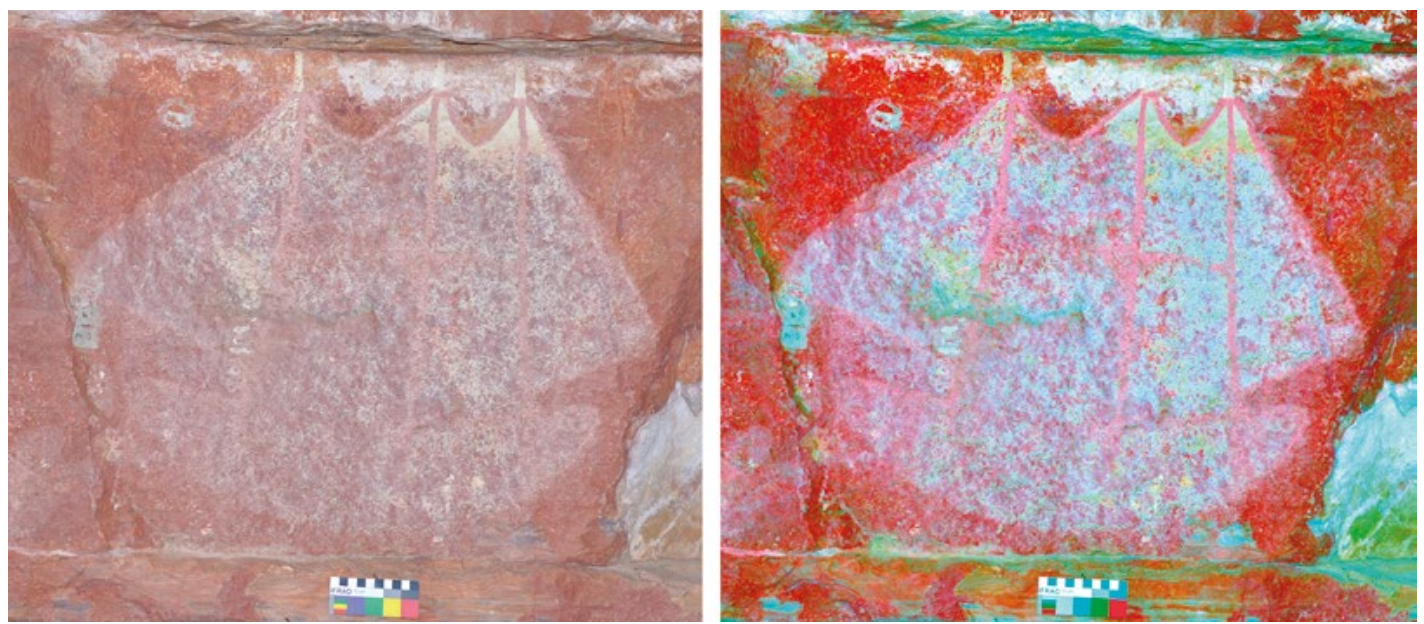

Figure 9.5 Boat E, site ARN-088/6. Left: Original image. Right: DStretch enhancement (ywe15). Scale $10 \mathrm{~cm}$.

Source: Photograph by Robert Gunn.

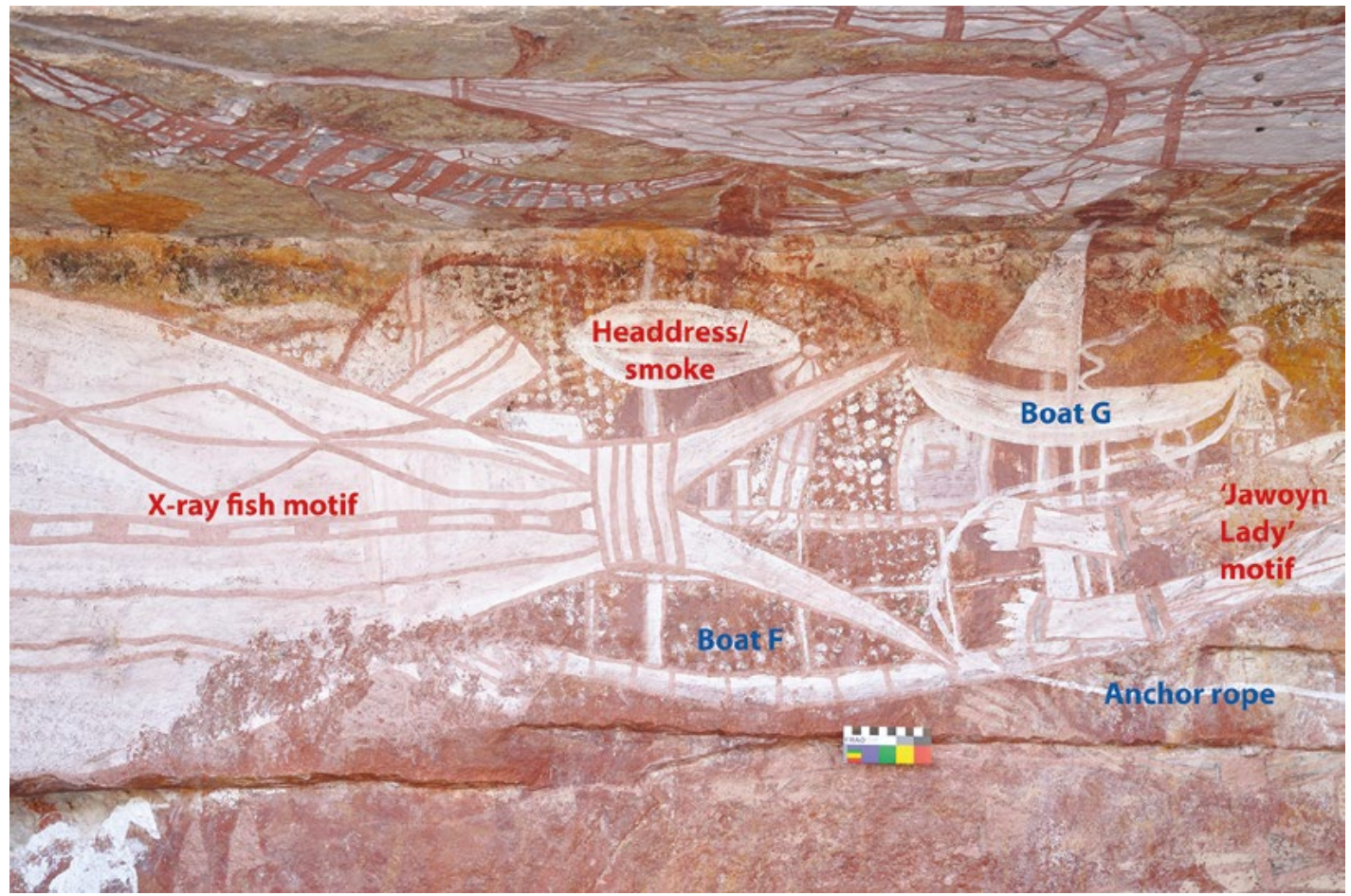

Figure 9.6 Overlapping boat motifs, site ARN-088/6. Scale $10 \mathrm{~cm}$.

Source: Photograph by Robert Gunn.

The larger vessel (Boat A; Figure 9.3) is most similar to either a three-masted schooner from the pearling industry or a river barge. The three smaller vessels (Boats B-D; Figure 9.4) are reminiscent of ocean-going sail canoes, schooners or coastal shunters (Paul Clark, pers. comm. 2010; David Steinberg, pers. comm. 2012). Those three smaller vessels exhibit features such as steering paddles/oars that suggest a non-European and non-south Sulawesi (Macassan) origin, with possible southern New Guinea or Tanimbar Islands (Maluku province east of Sulawesi) connections (Paul Clark, pers. comm. 2012). 
When visiting the site in 2008, the late Wamud Nadjamerrek, a senior Elder and rock art painter with close associations with Jawoyn lands (see Nadjamerrek et al. 2010), suggested that the boats at the Djurray shelter may have been painted as 'postcards' by visitors from the north coast of Arnhem Land to show Jawoyn people what they had seen (Wamud Nadjamerrek, pers. comm. to Ray Whear 2008). Given the many fine details of people and items of material culture in the paintings, the painter(s) themselves appear to have had considerable direct knowledge of the watercraft and their uses, reflecting their own personal experiences of having seen those vessels themselves rather than retelling second-hand knowledge. The depiction of the vessels is not entirely naturalistic, with some key features (such as the shape of the sails) being inaccurate and depicted in a non-functional manner (Adrian Horridge, pers. comm. 2012). This suggests that the boats were seen at a distance, perhaps in harbour, rather than the artist having knowledge of how they worked. Interestingly, Wamud Nadjamerrek showed greater interest in a pair of clap sticks shelved within a rock crevice at this site than in the boat paintings. Here, as at other Jawoyn art sites visited on this and other occasions, Wamud Nadjamerrek engaged more with the traditional images with which he could directly relate through his knowledge of cosmology or ceremony.

The boat images at the Djurray shelter are not the most recent paintings within this shelter, as two have been partially superimposed by large fish-like creatures in white with red outline and infill, one of which has X-ray features (Figure 9.6). The fish-like creature with the X-ray infill is painted in a similar manner to, and is similarly well-preserved as, a nearby large barramundi motif depicted with the classic X-ray form. The other fish-like creature has a spotted infill (sprayed dots); at the instruction of Wamud Nadjamerrek (pers. comm. to Robert Gunn 2008), it is not illustrated here due to its cultural sensitivities. For this chapter, this motif is simply termed the 'spotted fish'. Hence, the X-ray form of painting was being used here during the European-contact period. Similarly, Boat F has been superimposed by a large 'Jawoyn Lady' motif (Gunn 1992) in white with red and black infill (Figure 9.6), indicating that the 'Jawoyn Lady' motif type was also produced within the European-contact period. The anchor of the small sail boat (Boat G; Figure 9.6) passes neatly around the feet of the 'Jawoyn Lady' motif and over one of her toes, indicating that the anchor was added to the panel after the 'Jawoyn Lady' figure was painted. At some later time, as determined by patterns of superimposition, a white-infilled oval area - possibly a headdress or puff of tobacco smoke? - was added to the booted figure on Boat F (Figure 9.6). Comparable degrees of preservation suggest a range of other traditional motif types were also painted after Boats $F$ and G were painted. Together, these patterns of superimposition and states of preservation suggest that the painting of traditional motifs at the Djurray shelter continued well into the European-contact period. A pattern of X-ray paintings overlying European-contact motifs was also observed in the Wellington Range, $200 \mathrm{~km}$ to the north of Djurray and closer to the coast (Taçon et al. 2010:61).

\section{Other European contact-period images}

Seven other images referencing European contact-period items of material culture or considered to represent European-contact events have been located from six rockshelters in Jawoyn lands. These seven paintings consist of two of European people, a horse with rider, a horse without rider, a bullock with a neck-bell and two of metal-headed axe/hoes (Figures 9.7-9.14, 13.33).

One of the European figures (Figure 9.7) was painted in white on the rear wall of a shallow rockshelter, ARN-107/3. The person, $31 \mathrm{~cm}$ tall, wears a top hat and leans to their right, as if leaning casually against some unportrayed object. Despite standing with hands on hips, the person does not strike the forceful pose usually attributed to such a stance (Ouzman 2003:14). 
Aboriginal people across much of Australia characteristically used such a pose to depict European men (e.g. see also May et al. 2013:50). The pose is also depicted on the crew of Boat A at Djurray, $20 \mathrm{~km}$ to the northwest of ARN-107/3 (see above). The ARN-107/3 hatted person is positioned centrally on a vertical panel between two larger macropod paintings in a traditional style (Figure 9.7). Both macropod images were painted in white with red outline and infill that, from differences in pigment preservation, appear to pre-date the hatted person. The macropod to the right of the panel, however, shows evidence of repainting as water-wash across the legs reveals the original underpainting with the red outline. The repainting was in a similar monochrome white to the hatted person, and both whites are similarly preserved. This suggests that the painting of the hatted person and the repainting of the macropod are contemporaneous. No further paintings were added to this panel following these two white paintings. The presence of other, better preserved monochrome white paintings of traditional motifs in adjacent shelters, however, suggests either that the hatted person at $\mathrm{ARN}-107 / 3$ was painted during a phase of artistic activity that included other nearby rockshelters that provide better protection for their rock art, or that the hatted person was not the most recent image painted within this site complex.

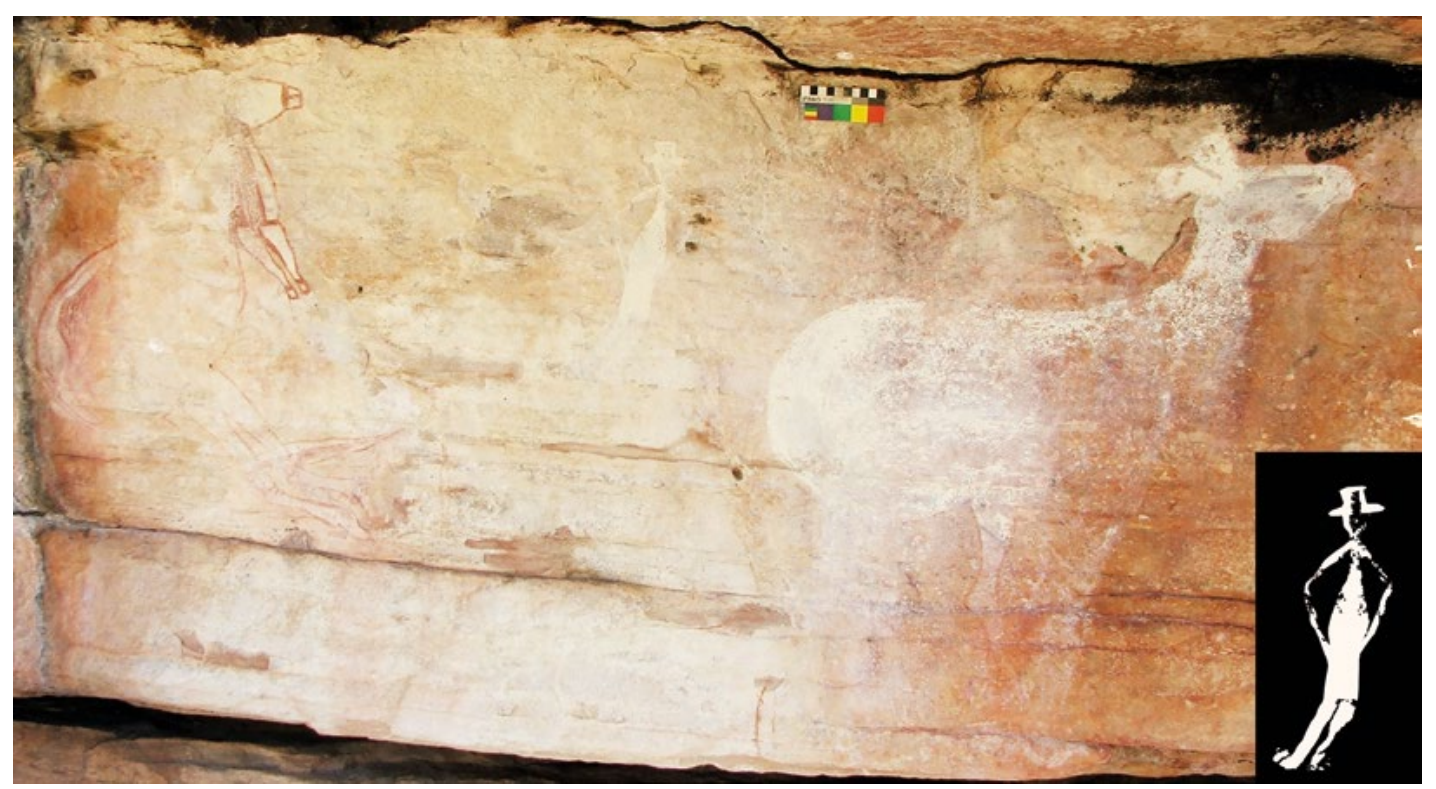

Figure 9.7 Art panel with European figure, site ARN-107/3. Insert is a photo-tracing of the central figure. Scale $10 \mathrm{~cm}$.

Source: Photograph by Robert Gunn.

A second human figure, arguably of the contact period and also painted in white (Figure 9.8), occurs in shelter ARN-019/M some $10 \mathrm{~km}$ east of Djurray. That figure is $70 \mathrm{~cm}$ tall and was painted on the underside of a rock ledge of an undercut rock wall $1.5 \mathrm{~m}$ above the floor. The painting is not visible from more than c. $1 \mathrm{~m}$ away. Here the human figure appears to be wearing a drooping hat (pith helmet?) of a shape not usually seen in the art of this region, and is holding a white bar across his hips. The shape of the bar (tapering from left to right) and the manner in which it is held suggest a rifle. This motif is one of seven white paintings in a similar state of preservation within the shelter; they are probably contemporaneous. None of the other six white paintings on an adjacent panel depict recognisably European-contact motifs. 


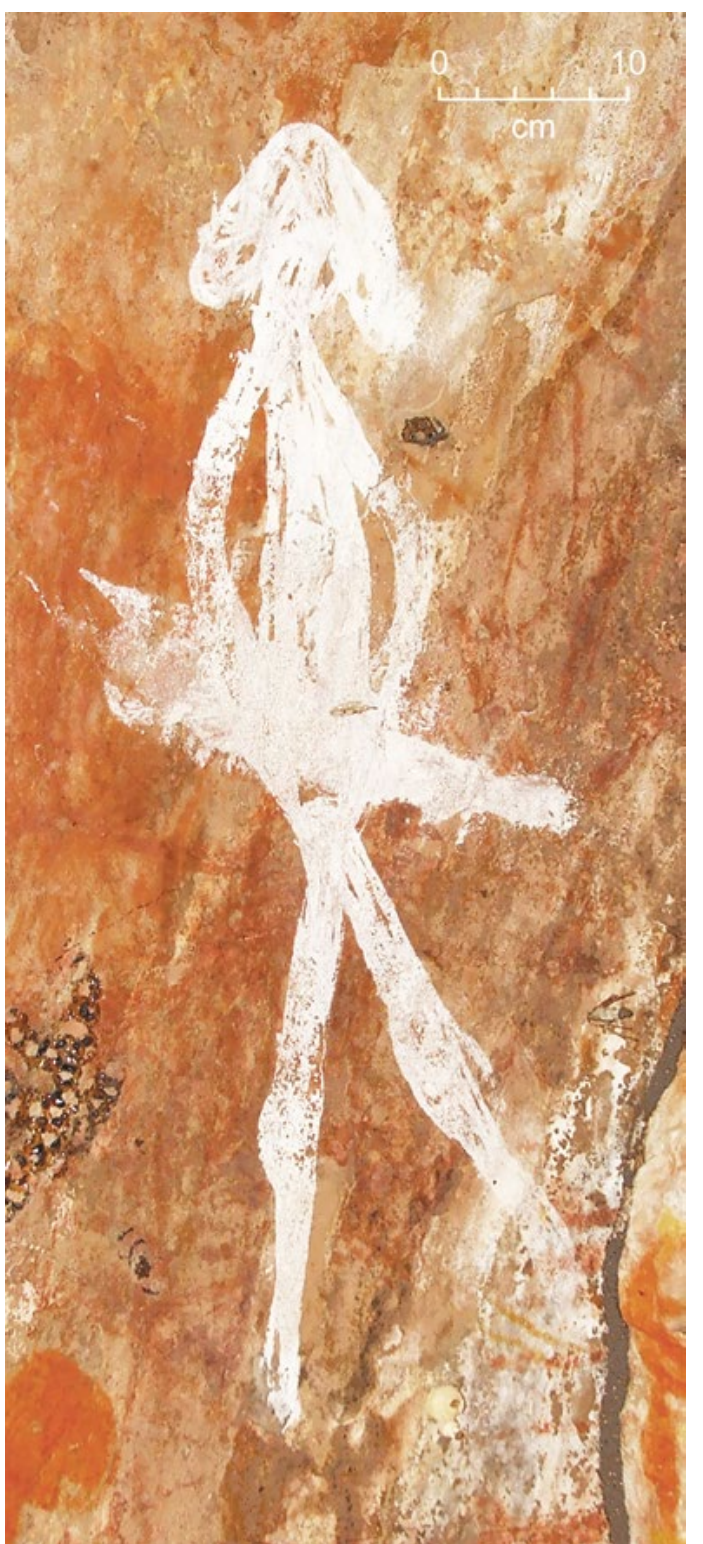

Figure 9.8 European figure with floppy hat and carrying a long object (rifle?), site ARN-019/M.

Source: Photograph by Robert Gunn.
At the remarkable and profusely decorated rockshelter site of Nawarla Gabarnmang (ARN-074/A), some $10 \mathrm{~km}$ to the south of Djurray, a large painting of a horse has been placed across a flat ceiling panel (Gunn et al. 2012a:61). The horse painting measures $3.5 \times 2.4 \mathrm{~m}$, on a multi-layered painted panel $4.7 \times 3.3 \mathrm{~m}$. Much of the horse is obscured by overlying, more recent paintings, but its overall shape can be tracked by connecting those parts of the horse that extend beyond the superimposing images, including its well-defined head, back and tail (Figure 9.9). The horse was painted with an unusual infill pattern; initially it was painted in a grey pigment, then outlined in white and then again in red. When completed, the painting would have been visually striking and readily apparent by anyone using the shelter. The many superimpositions on that panel (Figure 9.10) indicate that the horse was later overlain by at least four layers of paint represented by 17 paintings, including a number of X-ray fish and traditional Jawoyn-style anthropomorphs. The horse painting itself overlies another eight, and therefore older, layers of paint representing some 50 paintings of standard traditional Jawoyn motif types (such as macropods, 'spirit' figures, fish, turtle and hand stencils). None of the motifs under the horse are depicted in $\mathrm{X}$-ray. This sequence of superimpositions at Nawarla Gabarnmang, as with those involving European boats and more traditional motif forms at Djurray (see above), indicates the incorporation and articulation of new and traditional elements in the production of rock art over the European-contact period beginning with Leichhardt's travels across Arnhem Land in 1845 (cf. Gunn et al. 2012a) (see below). 


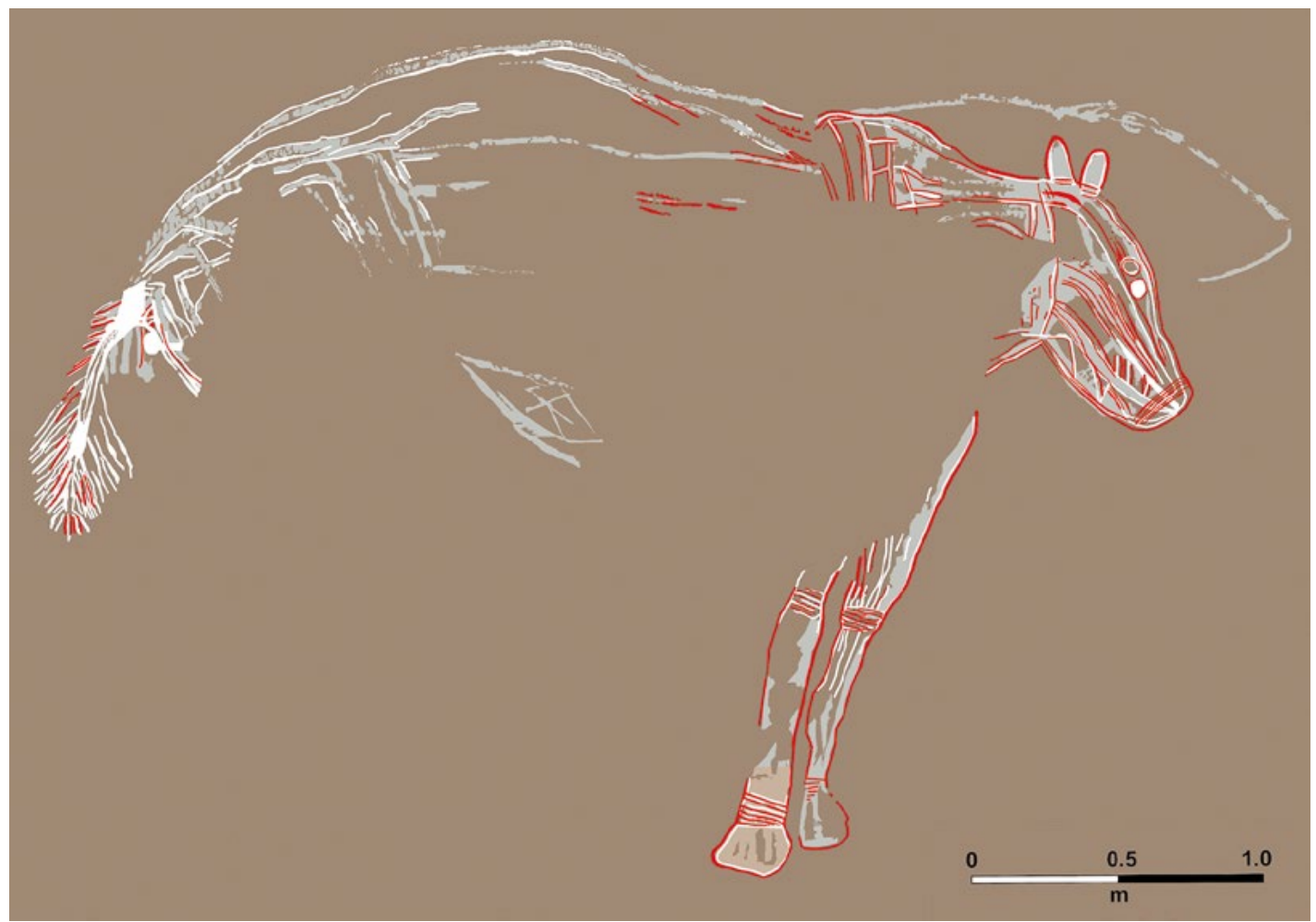

Figure 9.9 Horse painting, site ARN-074/A.

Source: Robert Gunn.

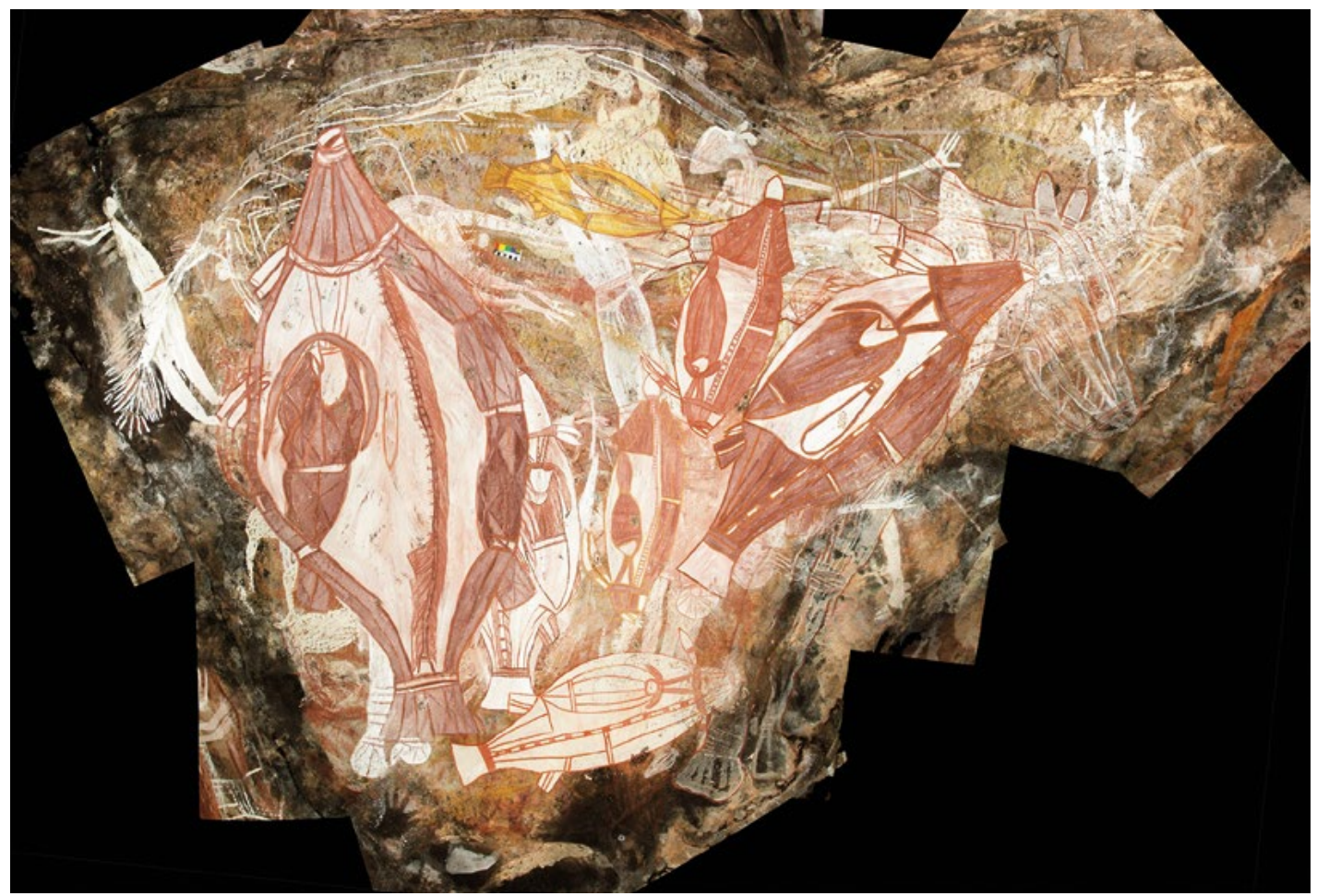

Figure 9.10 Panel with horse painting showing complex of superimpositions, site ARN-074/A. Head (at far right) and tail (at far left) of horse motif indicated. Scale $10 \mathrm{~cm}$. Source: Photograph by Robert Gunn. 
At the long but shallow shelter of site ARN-087/1, $15 \mathrm{~km}$ southeast of Djurray, an image of a person riding a horse was painted in red on the underside of a low ledge (Figures 9.11 and 9.12). The alcove is one of three conjoined alcoves that constitute the $70 \mathrm{~m}$ long shelter, which is prolifically decorated with over 600 images - mostly rows of small stick-figures - in all its alcoves. The horse-and-rider painting is $54 \mathrm{~cm}$ long. Along with many of the other images within this shelter, the horse-and-rider painting can only be viewed by lying on the floor beneath the ledge. The rider wears a broad, drooping hat similar to the one on the white figure at ARN019/M described above (Figure 9.8). A pair of reins, held by the rider, is clearly depicted and the criss-cross lines over the head appear to signify a halter, but no saddle is represented. The horse here has short front legs and longer hind legs, a kind of depiction more commonly seen on traditional paintings of macropods. The employment of this kind of macropod schema on early representations of horses was previously noted by Chaloupka (1993:195-196) for areas to the north of the plateau, to the north of Jawoyn lands. At ARN-087/1, the horse's tail was originally painted to curl between the hind legs, but was later repainted (i.e. corrected) to the standard tassel-like tail used on many other early contact paintings of horses elsewhere in Arnhem Land (Chaloupka 1993:200; Flood 1997:316; Lewis 1988:411; Murdoch 2009:1).

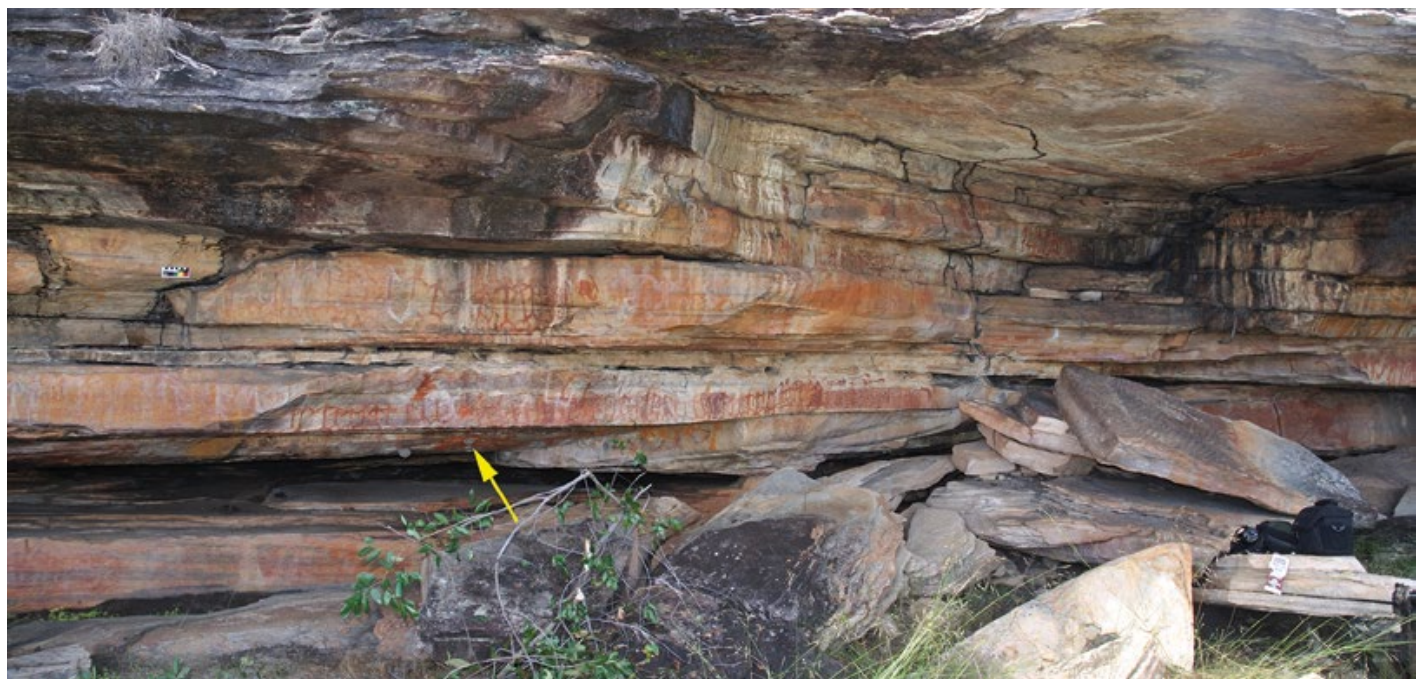

Figure 9.11 Site ARN-087/1 showing location of the horse-and-rider painting marked with yellow arrow.

Source: Photograph by Robert Gunn.
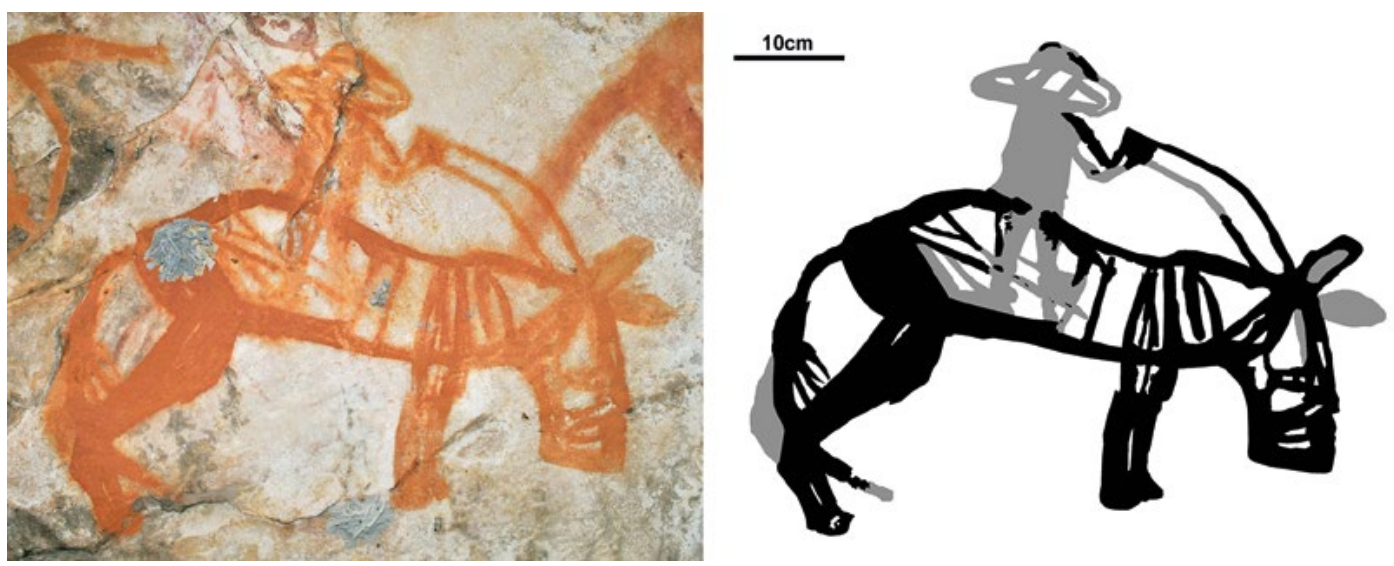

Figure 9.12 Horse-and-rider painting at site ARN-087/1.

Source: Photograph by Robert Gunn. 
Dalakngalarr 1 (ARN-082/1), $25 \mathrm{~km}$ east of Djurray, is another prolifically decorated shelter, with over 700 paintings. Two of the paintings are of metal-headed axe/hoes (see Figure 13.33). Both have typical swayed handles and large angular heads (see Figures 13.33B and 13.33D). The axe is painted in yellow with a purple outline and patterned infill, while the hoe is in plain yellow. Both axe/hoes are on the same outer wall section, to one side of the main occupation area, and superimpose at least one layer of earlier and considerably more faded red and yellow paintings. The colours and style of the axe at ARN-082/1 (see Figures 13.33A and 13.33B) are similar to those of a suite of adjacent X-ray fish paintings (Figure 9.15), suggesting that the axe is contemporaneous with the fish paintings. It also suggests that the X-ray paintings here, like the stylistically similar ones at Nawarla Gabarnmang, are a European-contact period addition to the shelter (see also Chapters 11 and 13).

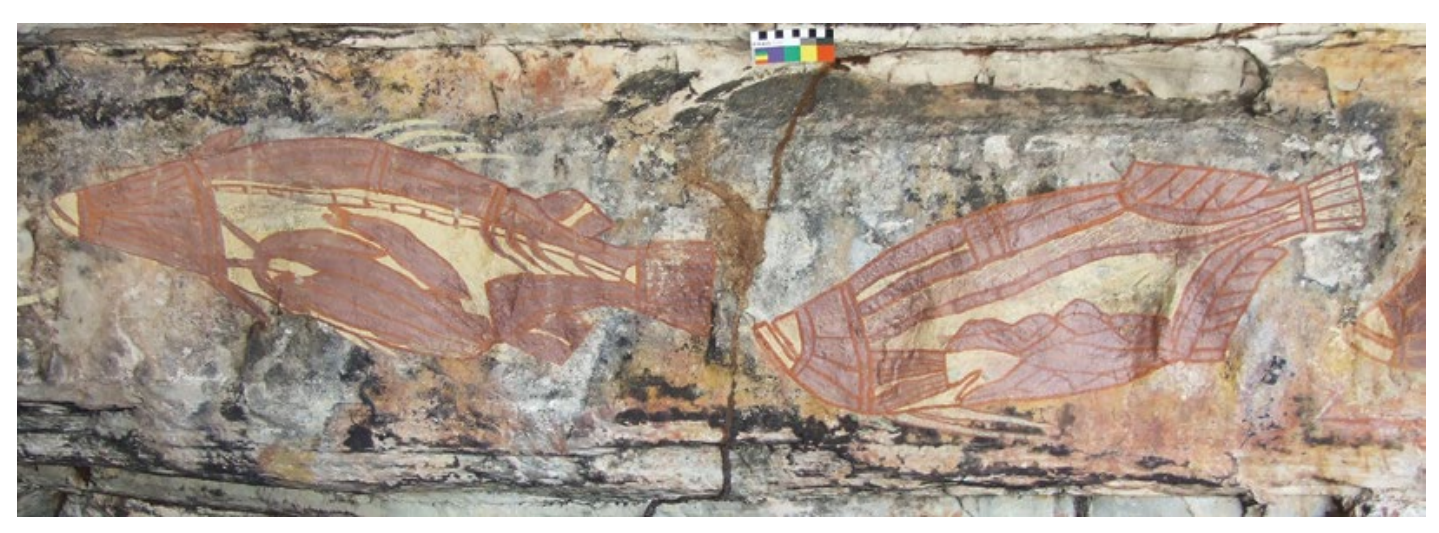

Figure $9.13 \mathrm{X}$-ray fish (barramundi and saratoga) painted with colours similar to those used on the axe painting, site ARN-082/1 (Dalakngalarr 1). Scale $10 \mathrm{~cm}$.

Source: Photograph by Robert Gunn.

The best preserved of the European-contact motifs on the plateau within Jawoyn lands is that of a bullock with neck-bell (Figure 9.13). It occurs on the rear wall of shelter ARN-031/1, towards the southern end of the plateau (Figure 9.2). The shelter is $28 \mathrm{~m}$ long and contains 360 mostly small paintings. The bullock is $67 \mathrm{~cm}$ long and painted with a white outline and striped infill, some of which has been discoloured by underlying yellow paintings. The bullock image is positioned centrally on a vertical panel and is one of the largest and clearest of the paintings in the shelter. Consequently, like the large boat (Boat A) at Djurray (see above), the bullock is the most notable image at ARN-031/1 (Figure 9.14). The bullock here appears to have been painted contemporaneously with an eel-tailed catfish (Tandanus tandanus) to its immediate right, where a similar pigment has been used; that eel-tailed catfish image is also outlined and stripe-infilled, with the two images being similarly well preserved. The eel-tailed catfish is $115 \mathrm{~cm}$ long and is positioned horizontally facing the bullock. Both the bullock and the catfish superimpose an array of poorly preserved white and yellow monochrome and white and red bichrome paintings, all of which overlie several layers of very faint red paintings. This sequence of superimpositions indicates that the bullock and the catfish are the final motifs painted on this panel. Their noticeably better state of preservation makes it likely that they were the last painted within the site complex. 


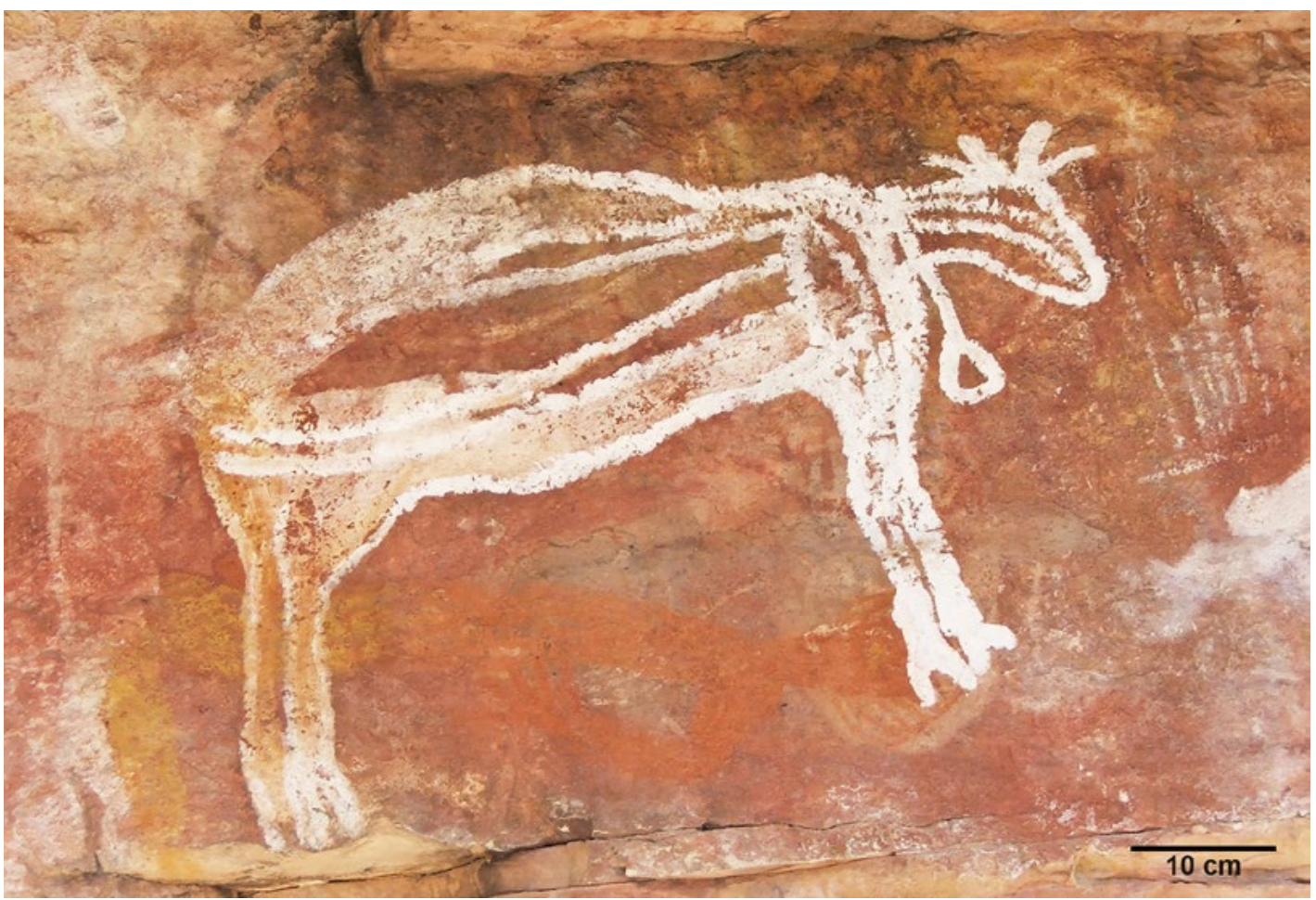

Figure 9.14 Bullock with bell panel, site ARN-031/1.

Source: Photograph by Robert Gunn.

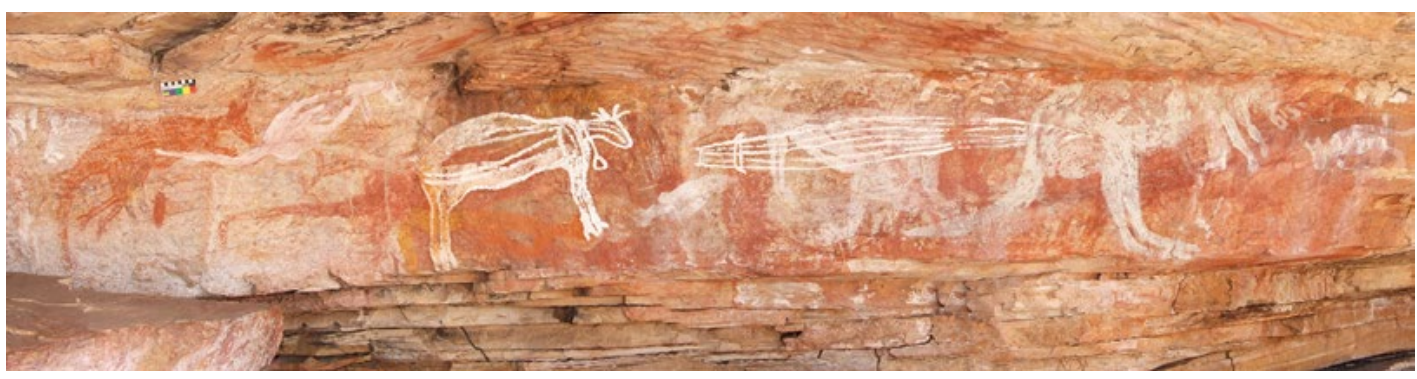

Figure 9.15 Panel of Bullock with bell, site ARN-031/1. Scale $10 \mathrm{~cm}$.

Source: Photograph by Robert Gunn.

\section{Overlying art}

Sixteen paintings, interpretable to motif type, have been recorded superimposed over Europeancontact motifs in Jawoyn lands (Table 9.2). These overlying paintings give an indication of artistic conventions demonstrably used during the period following initial European contact. The presence of X-ray fish and 'Jawoyn Lady' motifs over the contact motifs, and their absence below, indicate that they were part of the ensemble of artistic practices that followed initial European contact. While polychrome colouring may also be a feature of the rock art following initial European contact in Jawoyn lands, bichrome motifs also occur below, and hence precede, the production of the horse motif at Nawarla Gabarnmang. 


\section{Chemistry of white pigments from Boat A, the 'Jawoyn Lady' and a large spotted fish at Djurray site ARN-088/6: Identifying painting events}

Three small samples of white pigment were easily detached with the tip of a metal blade from Boat A, the 'Jawoyn Lady' and a large spotted fish to the left of Boat A (the latter cannot be shown for Jawoyn cultural reasons) at Djurray site ARN-088/6. The 'Jawoyn Lady' overlies Boat F, a demonstrably contact motif (see above for relationship to Boat G). We undertook specialist chemistry on the three detached samples to determine whether they were all painted with a single paint paste that would implicate a single painting event, or whether multiple events are more likely, as a means of further investigating the longevity of artistic practice into the period of European contact.

The three samples of white pigment were each examined under optical microscopy, revealing fine powder and clusters of powder grains (Table 9.3). Scanning Electron Microscope with Energy Dispersive X-ray Spectroscopy (SEM-EDS), using a LEO Stereoscan 440 SEM with a Brucker SDD X-FLASH 4030 EDS, indicates a crystalline structure of small plates for the Jawoyn Lady and spotted fish samples (Figures 9.16A and 9.16B). The plates of the spotted fish sample are composed mainly of $\mathrm{Al}$ and $\mathrm{Si}$ (at 1:1 ratio; Figure 9.16D). Specific alumino-silicate bands observed by Fourier Transform Infrared Spectroscopy (FTIR, using a Nicolet 380 spectrometer at $400-4000 \mathrm{~cm}^{-1}, 2 \mathrm{~cm}^{-1}$ resolution, 64 scans), indicate that each sample consists of kaolinite $\left(\mathrm{Al}_{2} \mathrm{Si}_{2} \mathrm{O}_{5}(\mathrm{OH})_{4}\right)$ (Figure 9.16C).

Table 9.2 List of paintings overlying European contact motifs in Jawoyn lands, southwestern Arnhem Land plateau.

\begin{tabular}{|c|c|c|c|}
\hline & \multicolumn{3}{|l|}{ Site } \\
\hline Time period & ARN-074 & \multicolumn{2}{|l|}{ ARN-088/6 } \\
\hline \multirow{5}{*}{ Most recent } & Polychrome X-ray fish $(\times 6)$ & \multirow[t]{5}{*}{ Bichrome fish-like creature } & White Boat $\mathrm{G}$ \\
\hline & Bichrome X-ray fish $(\times 2)$ & & \multirow[t]{4}{*}{ Bichrome 'Jawoyn Lady' and X-ray fish } \\
\hline & Bichrome 'Jawoyn Lady' (×2) & & \\
\hline & Bichrome anthropomorph & & \\
\hline & White macropod & & \\
\hline $\begin{array}{c}\text { Underlying } \\
\text { European-contact } \\
\text { motif }\end{array}$ & Polychrome horse & White Boat A & White Boat F \\
\hline
\end{tabular}

Source: Authors' data.

The presence of small, 10-15 $\mu \mathrm{m}$ long needle-like spicules of S-Ca in the 'Jawoyn Lady' and spotted fish samples is attributed to a calcium sulphate phase, probably indicating the presence of gypsum in stable, dry conditions. The presence of calcium sulphate could be due to natural precipitation on the wall, or anthropic mixing with the kaolinite pigment either to create a paint paste, or it could be unintentional as the kaolinite paint interacted with the surface of the rock wall. The weak presence of this calcium sulphate phase suggests a natural inclusion (i.e. contamination of the kaolinite) rather than anthropic mixing of components (i.e. intentional creation of a paint paste from multiple components). 
Table 9.3 Description of the pigment samples from Djurray site ARN-088/6.

\begin{tabular}{|c|c|c|c|}
\hline & \multicolumn{3}{|l|}{ PIGMENT SAMPLE } \\
\hline & Boat A & 'Jawoyn Lady' & Spotted fish \\
\hline General description & $\begin{array}{l}\text { Fine white powder }(<10 \mu \mathrm{m}) \\
\text { with few red and black grains } \\
(\text { c. } 30 \mu \mathrm{m})\end{array}$ & $\begin{array}{l}\text { Fine white powder } \\
(<10 \mu \mathrm{m}) \text { with few red and } \\
\text { black grains }(c .30 \mu \mathrm{m})\end{array}$ & White powder and powder clusters \\
\hline Major elements & Al, Si & Al, Si, S, Ca, P & Al, Si, S, Ca, P \\
\hline Minor elements & $\mathrm{Fe}, \mathrm{S}, \mathrm{Mg}, \mathrm{K}$ & K & $\mathrm{Fe}$ \\
\hline Morphology & Fine plates $(1-7 \mu \mathrm{m})$ & Fine plates $(1-7 \mu \mathrm{m})$ & $\begin{array}{l}\text { Fine plates }(1-7 \mu \mathrm{m}), \text { small rounded } \\
\text { grains }(10 \mu \mathrm{m}) \text { and larger crystals } \\
(10-20 \mu \mathrm{m})\end{array}$ \\
\hline $\begin{array}{l}\text { Mineralogical } \\
\text { identification }\end{array}$ & Kaolinite & Kaolinite & Kaolinite \\
\hline Overall constitution & $\begin{array}{l}\text { Kaolinite with trace of iron } \\
\text { oxide }\end{array}$ & $\begin{array}{l}\text { Kaolinite with few } \\
\text { impurities mixed with } \\
\text { gypsum, alumino-phosphate } \\
\text { phase and trace of Fe }\end{array}$ & $\begin{array}{l}\text { Kaolinite mixed with quartz grains, } \\
\text { gypsum and alumino-phosphate } \\
\text { phase }\end{array}$ \\
\hline
\end{tabular}

Source: Authors' data.

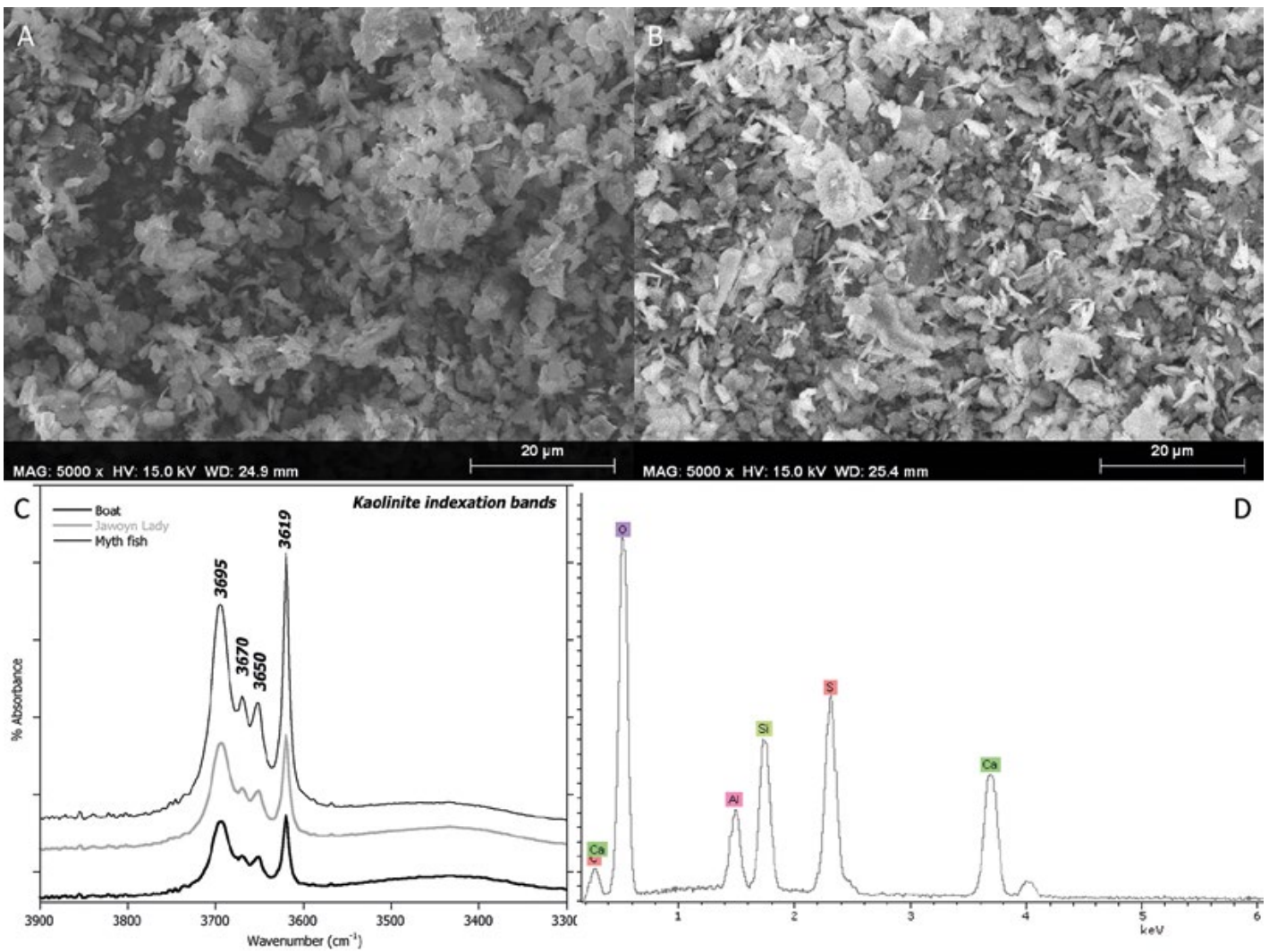

Figure 9.16 A: SEM-EDX (in secondary electron mode, $15 \mathrm{kV}$ ) micrograph of pigment sample from the 'Jawoyn Lady'. B: SEM-EDX (in secondary electron mode, $15 \mathrm{kV}$ ) micrograph of pigment sample from the spotted fish. C: FTIR spectra focused on the $3300-3900 \mathrm{~cm}^{-1}$ region. D: X-ray fluorescence spectrum from the spotted fish sample.

Source: Author's data. 
The 'Jawoyn Lady' and spotted fish samples exhibit large amounts of $\mathrm{P}$ in association with $\mathrm{Al}$, probably signalling an alumino-phosphate phase associated with weathering of the quartzite rock wall on which the paintings were undertaken.

Larger crystals of quartz $\left(\mathrm{SiO}_{2}\right)$ are only detected in the spotted fish sample. The quartz crystals probably came from the underlying rock rather than from the pigment. The composition of the spotted fish pigment sample differs a little from those of the other two pigment samples. This chemical difference in pigments may indicate either that the white paint from the spotted fish was prepared on a different occasion to that of Boat A and the 'Jawoyn Lady', or that different mixtures of paint paste were used contemporaneously on the different paintings. In addition, each of the three pigment samples exhibits its own unique combination of impurities $(\mathrm{Mg}, \mathrm{K}, \mathrm{Fe})$, suggesting multiple origins for the kaolinite pigment.

In summary, despite the common presence of kaolinite, the white pigments used to paint Boat A, the 'Jawoyn Lady' and the spotted fish each contain a different chemical signature, suggesting different combinations of elements and thus the use of different paint pastes or 'paint pots' (Chalmin et al. 2003). We cannot, therefore, confirm whether the three paintings imply a single painting event, as it is possible that the artist(s) had more than one paint paste with them during a single painting event, or whether the paintings were made on different occasions.

\section{The initial munanga contact period in Jawoyn lands}

The Jawoyn terms for non-Aboriginal people are munanga or mam (literally, 'devil' and/or 'white person'; Merlan and Jacq 2005). For several centuries prior to the European colonisation of Australia, Macassan sailors came annually to the northern coast of Arnhem Land to collect and process trepang (MacKnight 1972, 1986; Mitchell 1994; Mulvaney 1975; Taçon et al. 2010; Wesley et al. 2016). The extent of direct contact that inland groups such as the Jawoyn would have had with coastal mariners some $150 \mathrm{~km}$ to the northwest, if any, is unknown. Similarly, although British coastal outposts were established in 1827 at Fort Wellington (1827-1829) and in 1838 at Port Essington (1838-1849) - both to the northwest of the Arnhem Land plateau direct contact between Jawoyn and Europeans, or between Jawoyn and European animals such as horses and cattle, probably did not begin until Ludwig Leichhardt crossed the plateau from the southeast to the northwest in 1845 (Figure 9.17; Leichhardt 1847). Leichhardt's party travelled up the Flying Fox Creek valley that drains the southeastern side of the plateau on 1 November 1845. He noted in his journal that his party came across numerous Aboriginal camps and that he attempted to converse with and give gifts (such as brass buttons, horse-nails and a broken girth strap) to Aboriginal people whenever the chance arose (e.g. Leichhardt 1847:3 November 1845). Leichhardt and his party passed within $15 \mathrm{~km}$ southwest of Djurray and within $20 \mathrm{~km}$ southwest of Nawarla Gabarnmang (see Figure 9.17). Following an Aboriginal footpath beside the Roper River, to the south and southeast of the plateau, Leichhardt noted that 'cuts on various trees were made with an iron tomahawk' (Leichhardt 1847:19 October 1845) and, later, that while local Aboriginal people had seen or heard of 'white' people, they were much afraid of his party's horses and bullocks (Leichhardt 1847:22 October 1845).

Subsequent to Leichhardt's expedition, further exploration of the plateau by Europeans during the 1800 s was limited. In July 1862, J.M. Stuart passed through western Jawoyn Country in the southwestern corner of the plateau, but his party was wary of local Aboriginal people and only once did they exchange friendly greetings (Hardman 1865:25 June 1862). 


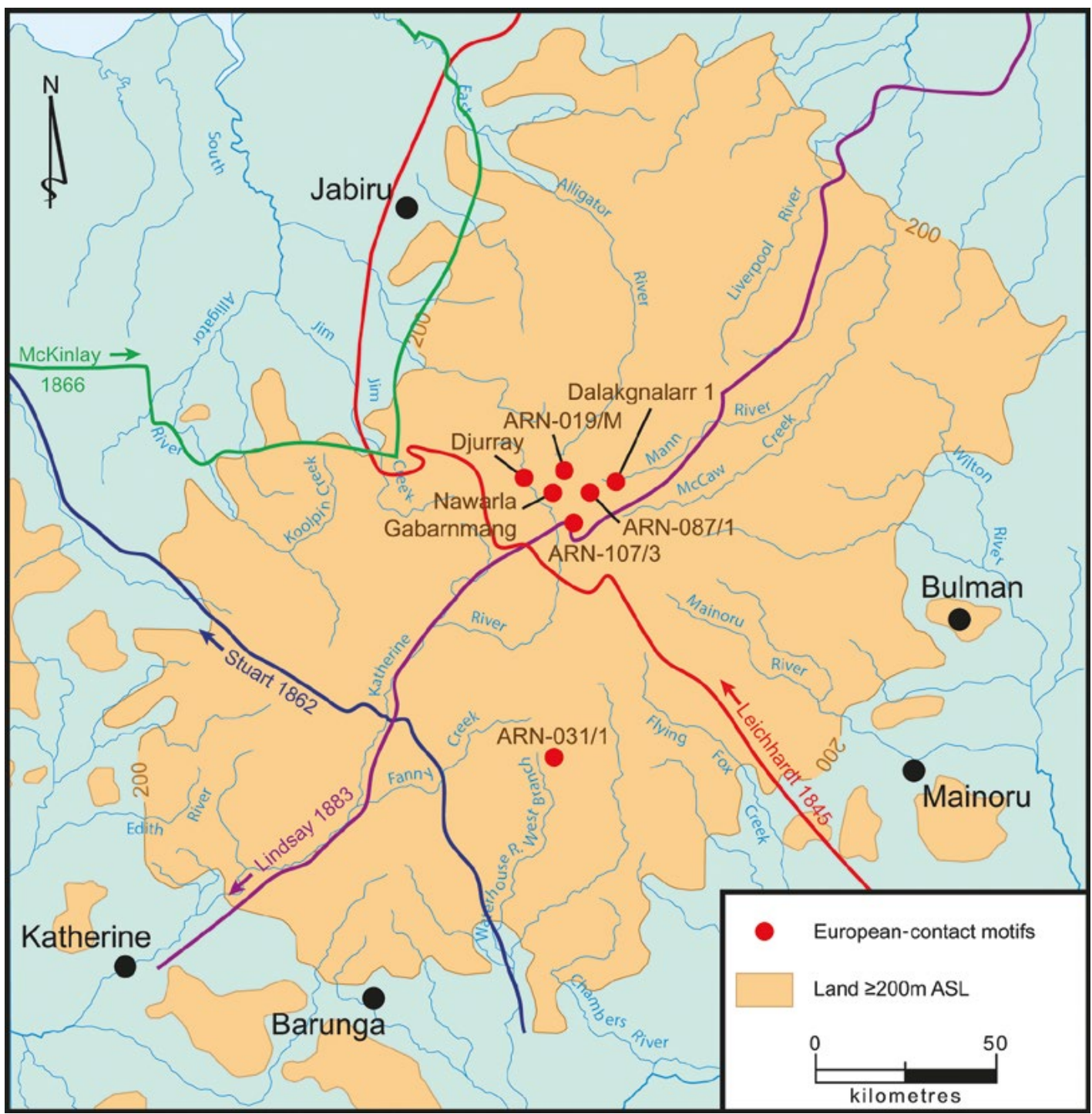

Figure 9.17 Early European travels on and around the Arnhem Land plateau. Leichhardt, Stuart, McKinlay and Lindsay's routes are plotted from maps and textual details in the explorers' published journals.

Source: Kara Rasmanis.

Four years later, J.M. McKinlay traversed the base of the northwestern escarpment (Australian Dictionary of Biography 1974; Davis 1863). Although McKinlay did not enter Jawoyn Country, doubtless his proximity would have been noticed by neighbouring groups and widely discussed.

In October 1883, David Lindsay, a government surveyor, was commissioned by the South Australian Government to assess the potential of eastern and central Arnhem Land for European settlement. Travelling by horse, Lindsay's party followed the Roper River from near the township of Katherine eastward around the south side of the plateau to the coast, deviating only to explore the upper reaches of the Wilton River. Cutting across the eastern, inland side of Arnhem Land they headed north to present-day Ramingining, west to the Liverpool River and then southwest over the plateau to the Katherine River, which they then followed downstream to the fledgling Katherine township (initially established as the Katherine Telegraph Station in 1872) (Figures 9.1 and 9.17). Lindsay was generally favourably disposed towards Aboriginal people and attempted to make peaceful contact with those he met, giving tobacco and small items (axes, fishing hooks and lines) in return for collecting word lists and receiving travel directions (Lindsay 1884). 
During two encounters, however - one near the mouth of the Roper River and one at Blue Mud Bay to the east of the Arnhem Land plateau - his party was attacked by armed warriors; Lindsay's party resorted to firearms to repel the assaults (McKinlay's party had also been threatened, on the East Alligator River).

Lindsay also mentions, and in some cases carefully describes, Aboriginal activities such as fishing and landscape-burning, as well as noting campsites, burial grounds and the location of stone quarries. From his notes, it is clear that the Roper River valley and the area around Ramingining were well populated by Aboriginal groups. Of the Roper River valley, which passes through southern Jawoyn lands, Lindsay writes: 'These evidences of an immense number of natives testifies to the excellence of the country' (Lindsay 1884:4). Despite his observations elsewhere, Lindsay makes no mention of seeing any people or campsite when crossing over the plateau on his return trip. It can be deduced from this lack of observations that the plateau was sparsely populated at that time. Whether this lack of encounters with Aboriginal people was due to the position of his route (which, to save his horses, deliberately avoided those areas where rock outcrops and rockshelters were densest), the effects of depopulation through earlier epidemics, or to the time of year (end of the dry season in October, when surface water is sparse) is unknown. Lindsay's party passed within $15 \mathrm{~km}$ of Djurray and $10 \mathrm{~km}$ south of the ARN-107 site complex, two key locations discussed in this chapter. With possible relevance for the paintings of horses at Nawarla Gabarnmang and the nearby ARN-087 site complex, it is of interest to note that the Aboriginal people Lindsay met near the western side of the Gulf of Carpentaria to the east of Jawoyn Country 'could speak a little English, were not afraid of us, but professed great fear of the horses and dogs' (Lindsay 1884:5). On another occasion, near the mouth of the Roper River, three of Lindsay's horses were speared by local Aborigines using spears tipped with either stone points or wire skewers. Before Lindsay could retrieve the wounded horses, one had been killed and disembowelled and his neck-bell taken (Lindsay 1884:6); during this early period when horses were first introduced into Arnhem Land, they were an object of keen interest to local Aboriginal groups.

Contact with munanga intensified with the completion of the overland telegraph line and the establishment of a repeater station near the present town of Katherine in 1872. The period between 1870 and 1890 also saw a rapid increase in the number of non-Aboriginal Australians, western Europeans and Chinese entering the western and southern sections of Jawoyn Country, as pastoral settlements became established and mineral exploration and gold-mining began (Levitus 1995:68-69, 74). Although few such intrusions were made onto the plateau, the pastoral industry isolated traditional waterholes and food reserves on surrounding lands, forcing local Aboriginal peoples to more or less rely on cattle stations, mines and/or market-gardens for labour and provisions to survive, at least seasonally. These places of work and access to resources became the foci of settlement for labourers and their families and, consequently, for the development of fringe camps. The presence of debilitating drugs such as opium, tobacco and alcohol, and often-rampant new diseases such as yaws and smallpox proved catastrophic, greatly reducing the population and thereby destroying or altering elements of culture, such as site-specific rites that required sizable gatherings for prolonged periods. By 1939, the Aboriginal population over most of the northern part of the Northern Territory, including the entire Arnhem Land plateau, had decreased dramatically, with estimated reductions of more than 95 per cent for each of the Alligator River region to the north and Victoria River region to the southwest of Jawoyn Country (Keen 1980; Rose 1992; Smith 1994:46). Following the Japanese bombing of Katherine in 1942, the Arnhem Land plateau was largely depopulated of Jawoyn and other Aboriginal groups through enforced resettlement into government compounds that later developed into residential communities, such as Rockhole at Katherine and small townships such as Barunga (Merlan 1998:5). 


\section{European contact-period occupation of the plateau}

'European contact' does not refer to a single period of time shared by all Aboriginal peoples across Australia. It, and its consequent effects on Aboriginal people, began at various times across the continent, depending on the timing of the expansion of European exploration and settlement. For the Guringai people of the Sydney region, initial European contact was in $1770 \mathrm{AD}$ and then again in $1788 \mathrm{AD}$ (McDonald 2008:16-22), while for some Western Desert groups initial European contact was not until around 1870 AD (Thompson 1975:x). For many Jawoyn, the European-contact period began in 1845 AD with Leichhardt's expedition across the plateau (above), that first phase of contact concluding with the development of local pastoral and mining industries in the 1890s. A second phase of contact in Jawoyn lands can be identified from $1890 \mathrm{AD}$ to the depopulation of the plateau in the 1940s. By the 1950s, the Maranboy tin mines had ceased production and most Jawoyn people from the plateau were now living in fringe camps around the towns and settlements off the plateau (Cooke 2009). Nevertheless, despite this broad exodus in the 1940s, Aboriginal people tell of continued movements across the region and of small numbers making prolonged visits to the plateau in the 1950s (Wamud Nadjamerrek and Margaret Katherine, pers. comm. 2006, 2010). Archaeologically, such a continued presence on the plateau is evident through at least two European-contact objects found in plateau rockshelters on Jawoyn lands: a decayed suitcase from site ARN-129/3 (Figure 9.18), likely to date to the first half of the 20th century; and a glass 'cat's-eye' marble (Figure 9.19) from site ARN-091/20a. Suitcases with similar catches to those at ARN-129/3 were being produced by 1911, and cat's-eye marbles began to be produced in the 1930s, gaining popularity in the 1940s and flooding the market in the 1950s. The glass marble could indicate occupation or visitation to the site in the 1930 s or early 1940 s, more likely in the post-World War II period after 1945 AD.
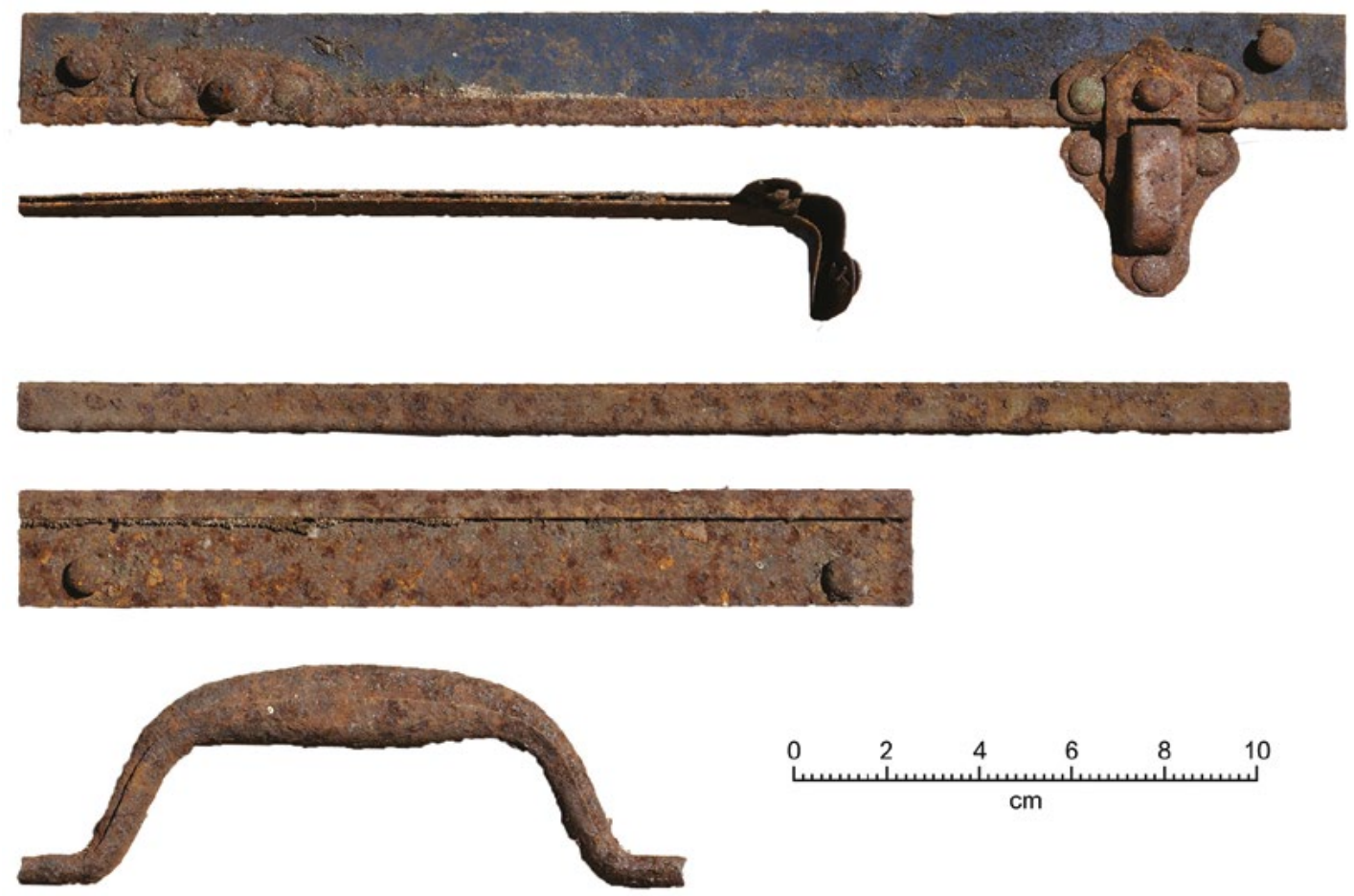

Figure 9.18 Suitcase frame elements from the European-contact period found as surface artefacts at site ARN-129/3.

Source: Photographs by Robert Gunn. 


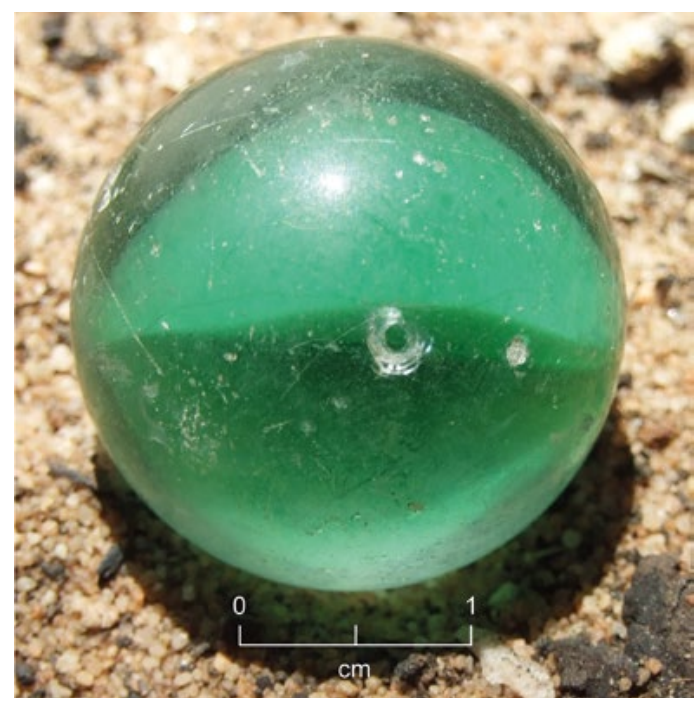

Figure 9.19 Cat's-eye marble from the Europeancontact period found as a surface artefact at site ARN-091/20a.

Source: Photograph by Robert Gunn.
Within Jawoyn lands on the Arnhem Land plateau, a number of portable artefacts of apparently limited antiquity have recently been found on rockshelter floors or carefully placed within rock outcrops. Those artefacts demonstrably from the European-contact period are those made of materials from nonAboriginal sources. To date, 45 artefacts of non-Aboriginal origins have been recorded from 33 site complexes (30 per cent of Jawoyn site complexes on the plateau) (Table 9.4).

Table 9.4 European contact-period artefacts found within rockshelters on the plateau (some sites contain more than one artefact type).

\begin{tabular}{|c|c|c|c|}
\hline Material & Artefact & \# of artefacts & \# of site complexes \\
\hline \multirow[t]{4}{*}{ Metal } & Metal piece & 4 & 4 \\
\hline & Tin can & 4 & 3 \\
\hline & Aluminium can & 1 & 1 \\
\hline & Suitcase & 1 & 1 \\
\hline \multirow[t]{3}{*}{ Glass } & Marble & 1 & 1 \\
\hline & Bottles & 1 & 1 \\
\hline & Beads & 2 & 2 \\
\hline \multirow[t]{2}{*}{ Cloth } & Bundle wrapping & 2 & 1 \\
\hline & Fragments & 4 & 3 \\
\hline \multirow[t]{8}{*}{ Wood cut with metal blade } & Burial poles & 4 & 2 \\
\hline & Clap sticks & 4 & 2 \\
\hline & Firewood & 2 & 2 \\
\hline & Highly carved small pointed implement & 1 & 1 \\
\hline & Barbed point & 5 & 4 \\
\hline & Piece & 3 & 3 \\
\hline & Pole & 3 & 1 \\
\hline & Ochred rods & 3 & 1 \\
\hline \multicolumn{2}{|l|}{ Total } & 45 & 33 \\
\hline
\end{tabular}

Source: Authors' data.

These items include objects or pieces of metal, glass or cloth (such as tin cans, iron nails, glass marbles, glass beads, canvas sheeting and so forth) (e.g. Figures 9.18-9.20; see Figure 13.32), and items made of wood such as barbed spear points, burial poles or cut firewood that have been clearly cut or fashioned by metal blades (e.g. Figures 9.21 and 9.22; see Figure 13.18). At Nawarla Gabarnmang (site ARN-074/A), the site with the large horse painting (see above), only one portable item of material culture demonstrably originating from non-Aboriginal sources 
has been found on the surface or in archaeological excavations: a blue glass bead $2.30 \times 2.56 \mathrm{~mm}$. The bead came from XU1 of excavation Square J, within the top $1.1 \mathrm{~cm}$ of sediment. Trade items were commonly carried by early European explorers travelling across northern Australia including Arnhem Land, although we do not know if they carried trade beads. As Wesley and Litster (2015) have noted, however, trade beads were present on the coast as currencies in AboriginalMacassan-European economies well before the first European explorers of the Arnhem Land plateau, and could thus have entered Jawoyn Country through northern Aboriginal interactions and movements. The absence of any known non-Aboriginal portable object other than the glass bead at Nawarla Gabarnmang indicates that the excavated bead was almost certainly deposited during the early (rather than later) European-contact period, and is likely to either precede, or to be broadly contemporaneous with, the horse painting located some $9 \mathrm{~m}$ to the southeast of Square J. Furthermore, of the 43 accelerator mass spectrometry (AMS) radiocarbon dates from near-surface charcoal dating to the past c. 400 years at Nawarla Gabarnmang (including from the area where the glass bead was found), not a single one exhibits evidence of the 'bomb pulse' (see below). The charcoal from the most recent campfires within the site thus almost certainly always pre-date $1945 \mathrm{AD}$ (by an unknown number of decades).

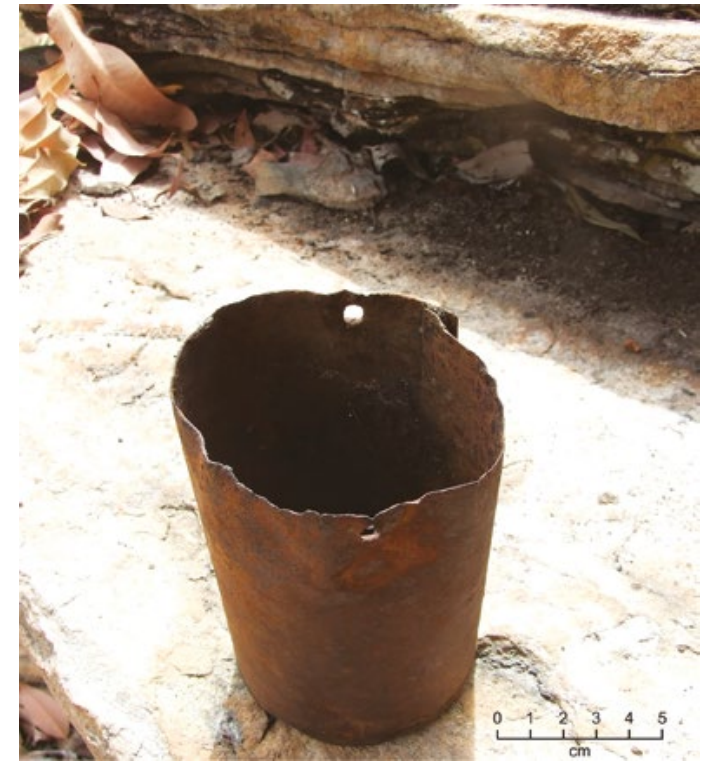

Figure 9.20 Small metal billy-can from the European-contact period found as a surface artefact at site ARN-116/1.

Source: Photograph by Robert Gunn.
Artefacts made from organic material such as plant fibre or wood are unlikely to survive for any extended period of time in Arnhem Land due to the acidic nature of the soils, the prevalence of termites and moulds, the scavenging activities of fauna (small to mediumsized mammals including dingoes, goannas, and birds), the high wet season rainfall, and the regular bushfires in the dry season (many initiated by the Jawoyn in the management of Country). Not surprisingly, therefore, most of the more recent artefacts recovered from rockshelters in Jawoyn lands, such as painted burial poles, ochred string, plant fibre bags and cloth pieces (e.g. Figures 9.23 and 9.24) come from sites close to European-period settlements located around the southern rim of the plateau, such as Barunga. Forty-seven artefacts made from locally available organic materials have been recorded from 35 site complexes (32 per cent of Jawoyn site complexes on the plateau) (Table 9.5).

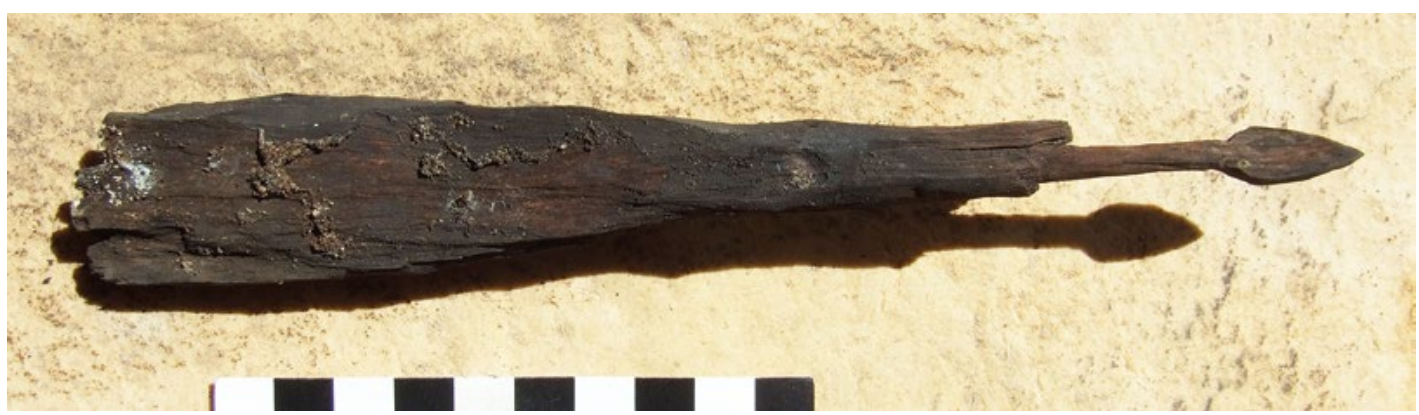

Figure 9.21 Non-European wooden artefact cut with a metal blade, site ARN-107/12. Scale $10 \mathrm{~cm}$.

Source: Photograph by Robert Gunn. 


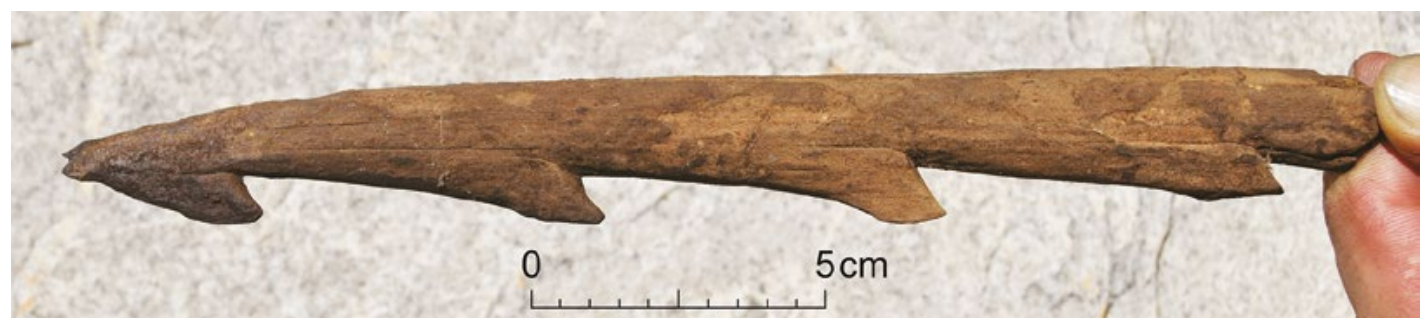

Figure 9.22 Non-European wooden spear point cut with metal blade, site ARN-133/29.

Source: Photograph by Robert Gunn.

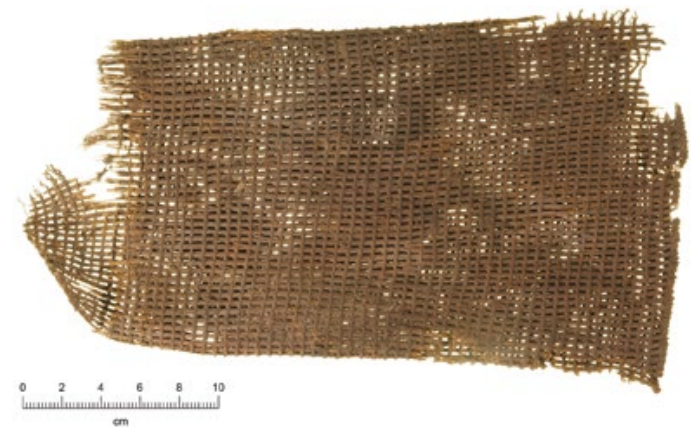

Figure 9.23 Non-European bag made from plant fibre, site ARN-110/1. Identified by Margaret Katherine (pers. comm. to Ray Whear 2009) as a bag for washing yams. AMS radiocarbon date Wk-31833 was obtained from a fragment of fibre from this bag.

Source: Photograph by Steve Morton.

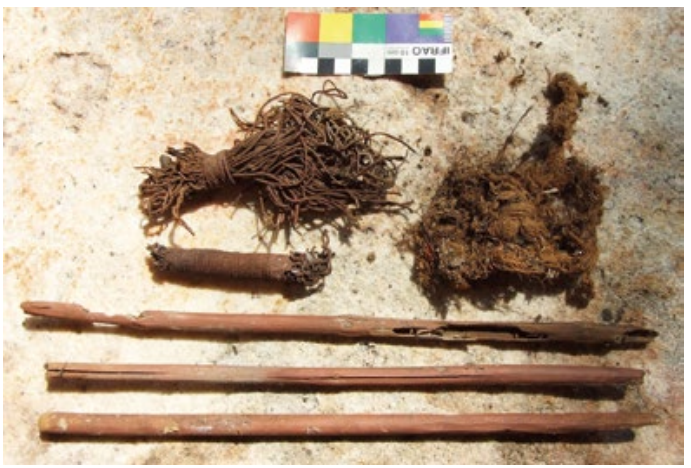

Figure 9.24 Non-European cache of cord and wooden artefacts, site EVA-12/4. Scale $10 \mathrm{~cm}$. Source: Photograph by Robert Gunn.

Table 9.5 Non-European artefacts made of organic materials found within rockshelters on the plateau (some sites contain more than one artefact type).

\begin{tabular}{|l|l|r|r|}
\hline Material & Artefact & \# of artefacts & \# of site complexes \\
\hline \multirow{5}{*}{ Fibre } & String skein & 1 & 1 \\
\cline { 2 - 4 } & Cord, tasselled \& ochred & 2 & 1 \\
\cline { 2 - 4 } & Fibre dillybag & 1 & 1 \\
\hline Paperbark & Sheets and bundle & 2 & 2 \\
\hline \multirow{3}{*}{ Other wood } & Cached stick & 3 & 3 \\
\cline { 2 - 4 } & Dillybag hook & 18 & 14 \\
\cline { 2 - 4 } & Bamboo shaft & 1 & 1 \\
\cline { 2 - 4 } & Wooden pole, straight & 3 & 2 \\
\cline { 2 - 4 } & Wooden pole, forked & 10 & 5 \\
\cline { 2 - 4 } & Wooden spear point, plain & 3 & 2 \\
\cline { 2 - 4 } & Other wooden implements & 3 & 3 \\
\hline \multirow{2}{*}{ Total } & & 47 & 25 \\
\hline
\end{tabular}

Source: Authors' data. 
In an attempt to establish the most recent use of the Arnhem Land plateau sites, surface and near-surface (i.e. most recent) in situ hearths on the Arnhem Land plateau were radiocarbondated (Table 9.6). Although few such surface cultural features have been encountered so far, the results are instructive. All bar one of these hearths are located within rockshelters; the exception is a hearth from an eroding creek bank at the ARN-079 rock art site complex (Table 9.6). Installations and portable items of material culture found on the surface of sites have also been radiocarbon-dated with these same aims in mind, including two canine bundle burials (Gunn et al. 2010, 2012b), a plant fibre dillybag (Figure 9.23), and four wooden items of material culture (Figure 9.25; see below). Direct radiocarbon dating of apparently relatively recent rock art has also been undertaken, in particular of beeswax figures (Gunn and Whear 2008).

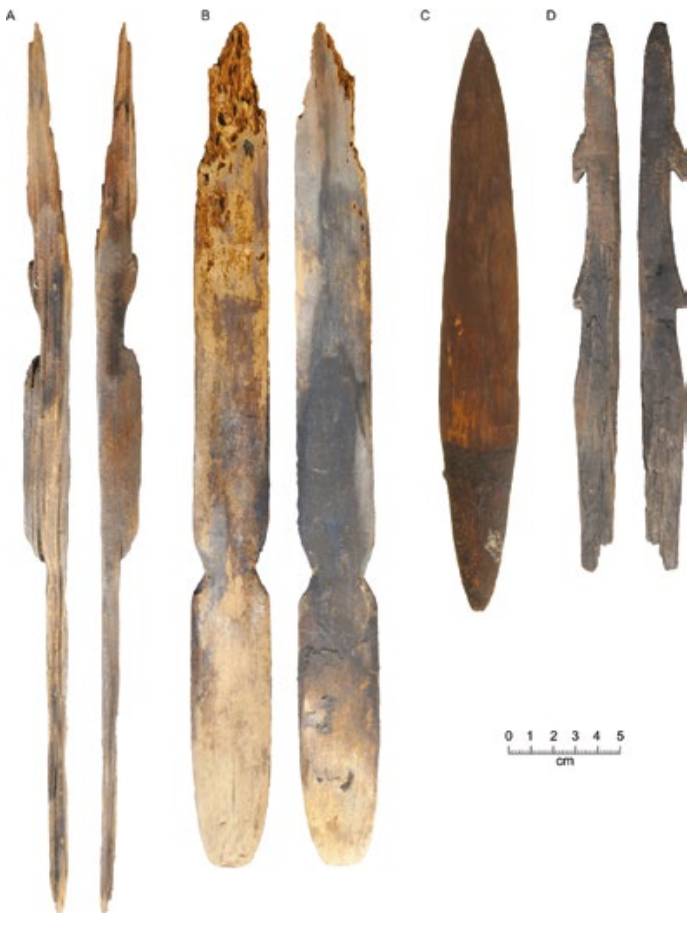

Figure 9.25 Non-European artefacts made of wood. A: Barbed spear point with radiocarbon date Wk-28114, site ARN-074/A. B: Spearthrower with radiocarbon date Wk-28113, site ARN-074/A. C: Point with adhering resin with radiocarbon date Wk-31834, site ARN-087/1. D: Barbed spear point with radiocarbon dates Wk-28115 and Wk31835, site ARN-074/A.

Source: Photographs by Bruno David, Steve Morton and Jean-Michel Geneste.
The testing of atomic bombs in the 1950s and early 1960s significantly increased the amount, and proportion, of ${ }^{14} \mathrm{C}$ in the atmosphere, so that radiocarbon dates with very high levels of ${ }^{14} \mathrm{C}$ exceeding the 1955 levels exhibit evidence of the 'bomb pulse', and can be used to date post-1955 samples to within six months' precision (e.g. see Wilson et al. 2001). It is significant that none of the radiocarbon dates from objects on the plateau in Jawoyn lands exhibit the bomb pulse. Of the six surface and near-surface hearths dated, the two most recent calibrate to sometime within the period 1693-1956 AD at 68.3 per cent probability, but most probably within the mid-1800 to early 1900s; so they almost certainly either predate the European-contact period or date to its early phase prior to depopulation of the plateau by 1942 . Similarly, both canine burials have a higher probability of calibrating to within the period 1877-1917 AD, again signalling ages of the early European-contact period prior to the bomb pulse. All six radiocarbon dates from the fragile (i.e. arguably relatively recent) wooden and plant fibre artefacts (Figures 9.23 and 9.25) recovered from shelter floors calibrate to within the period 1651-1956 AD, but again the highest probability age ranges fall in the 18th and 19th centuries relating to the pre- or early European-contact period and certainly to an overall period preceding the bomb pulse. The youngest five radiocarbon-dated beeswax images, similarly, all have highest probability peaks in the 18th and 19th centuries. Thus, all the cultural items investigated because they might be of very recent age are most likely of the early European-contact period or earlier, indicating a paucity or absence of traces of occupation into more recent times (Table 9.6). 
Table 9.6 Radiocarbon determinations on surface cultural features on the plateau, Jawoyn lands.

\begin{tabular}{|c|c|c|c|c|c|c|}
\hline Site complex & $\begin{array}{l}\text { Wk- laboratory } \\
\text { code }\end{array}$ & $\theta^{13} \mathrm{C} \% 0$ & $\begin{array}{l}\text { \% Modern } \\
\text { carbon }\left(\mathrm{F}^{14} \mathrm{C} \%\right)\end{array}$ & $\begin{array}{l}{ }^{14} \text { C age } \\
\text { (years BP) }\end{array}$ & $\begin{array}{l}\text { Calibomb 1yr smoothing } \\
\text { (68.3\% probability) }\end{array}$ & $\begin{array}{l}\text { European- } \\
\text { contact period }\end{array}$ \\
\hline \multicolumn{7}{|c|}{ Charcoal from surface hearths } \\
\hline ARN-115 & 30145 & $-25.4 \pm 0.2$ & $99.4 \pm 0.3$ & $51 \pm 25$ & \begin{tabular}{|l|}
$1708-1718(0.144)$ \\
$1826-1832(0.066)$ \\
$1887-1912(0.771)$ \\
$1956-1956(0.019)$ \\
\end{tabular} & Probable \\
\hline ARN-055 & 30143 & $-25.5 \pm 0.2$ & $98.6 \pm 0.2$ & $115 \pm 35$ & \begin{tabular}{|l|l|}
$1693-1707(0.149)$ \\
$1719-1727(0.094)$ \\
$1812-1826(0.137)$ \\
$1832-1885(0.558)$ \\
$1913-1919(0.062)$ \\
\end{tabular} & Probable \\
\hline ARN-055 & 30144 & $-24.1 \pm 2.0$ & $96.9 \pm 0.2$ & $254 \pm 32$ & $1645-1660(1.000)$ & No \\
\hline ARN-067 & 31071 & $-25.3 \pm 0.2$ & $95.7 \pm 0.4$ & $352 \pm 33$ & \begin{tabular}{|l|}
$1473-1523(0.470)$ \\
$1560-1560(0.000)$ \\
$1572-1630(0.530)$ \\
\end{tabular} & No \\
\hline ARN-087 & 31072 & $-26.1 \pm 0.2$ & $77.5 \pm 0.4$ & $2052 \pm 38$ & $\begin{array}{l}148-142 \text { BC }(0.033) \\
112 \text { BC-AD } 3(0.967)\end{array}$ & No \\
\hline ARN-079 & 25687 & $-25.4 \pm 0.2$ & $63.3 \pm 0.2$ & $3671 \pm 36$ & $\begin{array}{l}2131-2084 \text { BC (0.579) } \\
2056-2022 \text { BC }(0.375) \\
1990-1984 \text { BC }(0.046) \\
\end{array}$ & No \\
\hline \multicolumn{7}{|l|}{ Canine (dog) bone } \\
\hline ARN-107 (dingo) & 25381 & $-13.5 \pm 0.2$ & $99.0 \pm 0.3$ & $77 \pm 35$ & \begin{tabular}{|l|}
$1698-1722(0.285)$ \\
$1817-1834(0.199)$ \\
$1879-1916(0.514)$ \\
$1956-1956(0.001)$ \\
\end{tabular} & Probable \\
\hline ARN-057 (dog) & 31813 & $n / a$ & $98.9 \pm 0.3$ & $88 \pm 25$ & \begin{tabular}{|l}
$1697-1725(0.317)$ \\
$1815-1835(0.225)$ \\
$1877-1917(0.459)$ \\
\end{tabular} & Probable \\
\hline \multicolumn{7}{|l|}{ Beeswax art } \\
\hline ARN-117 & 26415 & $-23.0 \pm 0.2$ & $98.3 \pm 0.2$ & $136 \pm 30$ & \begin{tabular}{|l|}
$1681-1697(0.144)$ \\
$1724-1739(0.123)$ \\
$1744-1763(0.124)$ \\
$1802-1815(0.107)$ \\
$1835-1878(0.311)$ \\
$1916-1938(0.183)$ \\
$1954-1955(0.004)$ \\
$1955-1956(0.004)$ \\
\end{tabular} & Possible \\
\hline ARN-063 & 19299 & $-24.4 \pm 0.2$ & $98.2 \pm 0.4$ & $143 \pm 31$ & $\begin{array}{l}1674-1696(0.152) \\
1725-1778(0.364) \\
1799-1814(0.107) \\
1836-1844(0.047) \\
1851-1869(0.112) \\
1871-1876(0.029) \\
1917-1941(0.178) \\
1954-1956(0.011) \\
\end{array}$ & Possible \\
\hline ARN-074 & 26418 & $-24.8 \pm 0.2$ & $98.1 \pm 0.2$ & $153 \pm 30$ & \begin{tabular}{|l|}
$1677-1688(0.138)$ \\
$1730-1765(0.496)$ \\
$1772-1776(0.042)$ \\
$1800-1809(0.126)$ \\
$1926-1940(0.199)$ \\
\end{tabular} & Possible \\
\hline ARN-074 & 28101 & $-22.9 \pm 0.2$ & $97.9 \pm 0.3$ & $173 \pm 30$ & \begin{tabular}{|l|}
$1669-1683(0.173)$ \\
$1735-1781(0.557)$ \\
$1798-1806(0.094)$ \\
$1930-1945(0.176)$
\end{tabular} & Possible \\
\hline
\end{tabular}




\begin{tabular}{|c|c|c|c|c|c|c|}
\hline Site complex & $\begin{array}{l}\text { Wk- laboratory } \\
\text { code }\end{array}$ & $\theta^{13} \mathrm{C} \% 0$ & $\begin{array}{l}\text { \% Modern } \\
\text { carbon }\left(\mathrm{F}^{14} \mathrm{C} \%\right)\end{array}$ & $\begin{array}{l}{ }^{14} \text { C age } \\
\text { (years BP) }\end{array}$ & $\begin{array}{l}\text { Calibomb 1yr smoothing } \\
\text { (68.3\% probability) }\end{array}$ & $\begin{array}{l}\text { European- } \\
\text { contact period }\end{array}$ \\
\hline ARN-063 & 19317 & $-24.3 \pm 0.2$ & $97.6 \pm 0.4$ & $195 \pm 31$ & $\begin{array}{l}1661-1681(0.226) \\
1738-1753(0.129) \\
1762-1803(0.463) \\
1937-1951(0.167) \\
1952-1954(0.016)\end{array}$ & Possible \\
\hline $\begin{array}{l}\text { ARN-074 } \\
\text { (resin?) }\end{array}$ & 31731 & $-12.2 \pm 0.2$ & $96.7 \pm 0.3$ & $267 \pm 29$ & 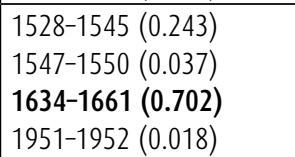 & No \\
\hline ARN-074 & 31722 & $-24.1 \pm 0.2$ & $96.0 \pm 0.4$ & $327 \pm 31$ & \begin{tabular}{|l|}
$1499-1504(0.044)$ \\
$1512-1531(0.178)$ \\
$1537-1601(0.592)$ \\
$1616-1635(0.186)$
\end{tabular} & No \\
\hline ARN-074 & 31721 & $-24.2 \pm 0.2$ & $95.9 \pm 0.3$ & $340 \pm 25$ & $\begin{array}{l}1493-1526(0.320) \\
1555-1602(0.483) \\
1614-1633(0.197)\end{array}$ & No \\
\hline ARN-074 & 26416 & $n / a$ & $95.3 \pm 0.2$ & $383 \pm 30$ & \begin{tabular}{|l|}
$1452-1487(0.942)$ \\
$1604-1607(0.058)$
\end{tabular} & No \\
\hline ARN-074 & 26414 & $-23.3 \pm 0.2$ & $95.1 \pm 0.2$ & $406 \pm 30$ & $1447-1471(1.000)$ & No \\
\hline ARN-063 & 19318 & $-22.9 \pm 0.2$ & $86.9 \pm 0.3$ & $1124 \pm 32$ & \begin{tabular}{|l|}
$890-907(0.236)$ \\
$915-968(0.764)$
\end{tabular} & No \\
\hline \multicolumn{7}{|c|}{ Organic portable artefacts } \\
\hline $\begin{array}{l}\text { ARN-074 } \\
\text { (wood from } \\
\text { spearthrower) }\end{array}$ & 28113 & $-25.0 \pm 0.2$ & $99.4 \pm 0.3$ & $47 \pm 30$ & \begin{tabular}{|l|}
$1708-1718(0.144)$ \\
$1826-1832(0.066)$ \\
$1887-1912(0.771)$ \\
$1956-1956(0.019)$
\end{tabular} & Probable \\
\hline $\begin{array}{l}\text { ARN-074 (wood } \\
\text { from clap stick) }\end{array}$ & 28116 & $-25.3 \pm 0.2$ & $98.8 \pm 0.4$ & $99 \pm 32$ & 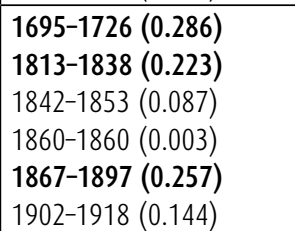 & Possible \\
\hline $\begin{array}{l}\text { ARN-087 (resin } \\
\text { from spear point } \\
\text { hafting) }\end{array}$ & 31834 & $-23.1 \pm 0.2$ & $98.7 \pm 0.3$ & $109 \pm 25$ & 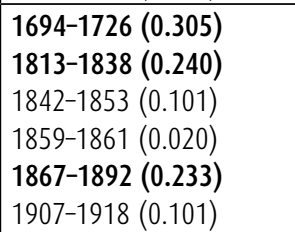 & Possible \\
\hline $\begin{array}{l}\text { ARN-110 (plant } \\
\text { fibre from } \\
\text { dillybag) }\end{array}$ & 31833 & $-10.1 \pm 0.2$ & $98.4 \pm 0.3$ & $127 \pm 25$ & $\begin{array}{l}1670-1685(0.164) \\
1731-1780(0.542) \\
1798-1808(0.105) \\
1927-1944(0.177) \\
1954-1955(0.012)\end{array}$ & Doubtful \\
\hline \multirow{2}{*}{$\begin{array}{l}\text { ARN-074 (wood } \\
\text { from barbed } \\
\text { spear point) }\end{array}$} & 28115 & $-23.7 \pm 0.2$ & $98.0 \pm 0.3$ & $159 \pm 30$ & \multirow[b]{2}{*}{$\begin{array}{l}1666-1681(0.239) \\
1739-1750(0.119) \\
1762-1784(0.335 \\
1795-1802(0.105) \\
1937-1950(0.194) \\
1953-1954(0.009)\end{array}$} & \multirow[t]{2}{*}{ Doubtful } \\
\hline & 31835 & $-24.2 \pm 0.2$ & $97.2 \pm 0.4$ & $227 \pm 30$ & & \\
\hline $\begin{array}{l}\text { ARN-074 (wood } \\
\text { from barbed } \\
\text { spear point) }\end{array}$ & 28114 & $-23.9 \pm 0.2$ & $97.3 \pm 0.3$ & $218 \pm 30$ & $\begin{array}{l}1651-1669(0.415) \\
1781-1798(0.432) \\
1946-1953(0.153)\end{array}$ & Doubtful \\
\hline
\end{tabular}

All ${ }^{14} \mathrm{C}$ ages are AMS on single pieces of charcoal (hearths), bone (canine bone), beeswax or probable plant resin (rock art), wood or plant fibre (portable artefacts). Calibrations undertaken using Calibomb (IntCal13 and SHZ3) (Reimer et al. 2013; Hua et al. 2013). Numbers in bold represent the highest probability range.

Source: Authors' data. 
The distribution of these artefacts and dates across Jawoyn lands on the plateau (Figure 9.26) reveals evidence of people using rock art sites during the early European-contact period. The paucity of European-contact motifs relating to this early contact period cannot be seen simply as a reduction in population numbers. Nor can it be due to a reduction in artistic output over this same time frame, as well shown for example by the heavy superimpositioning at ARN074/A when output increases and images become bigger and are more polychrome. The evidence indicates that Aboriginal people remained numerous over many decades on the plateau during the early European-contact period. An explanation is called for other than rapid depopulation close to the initial period of contact.

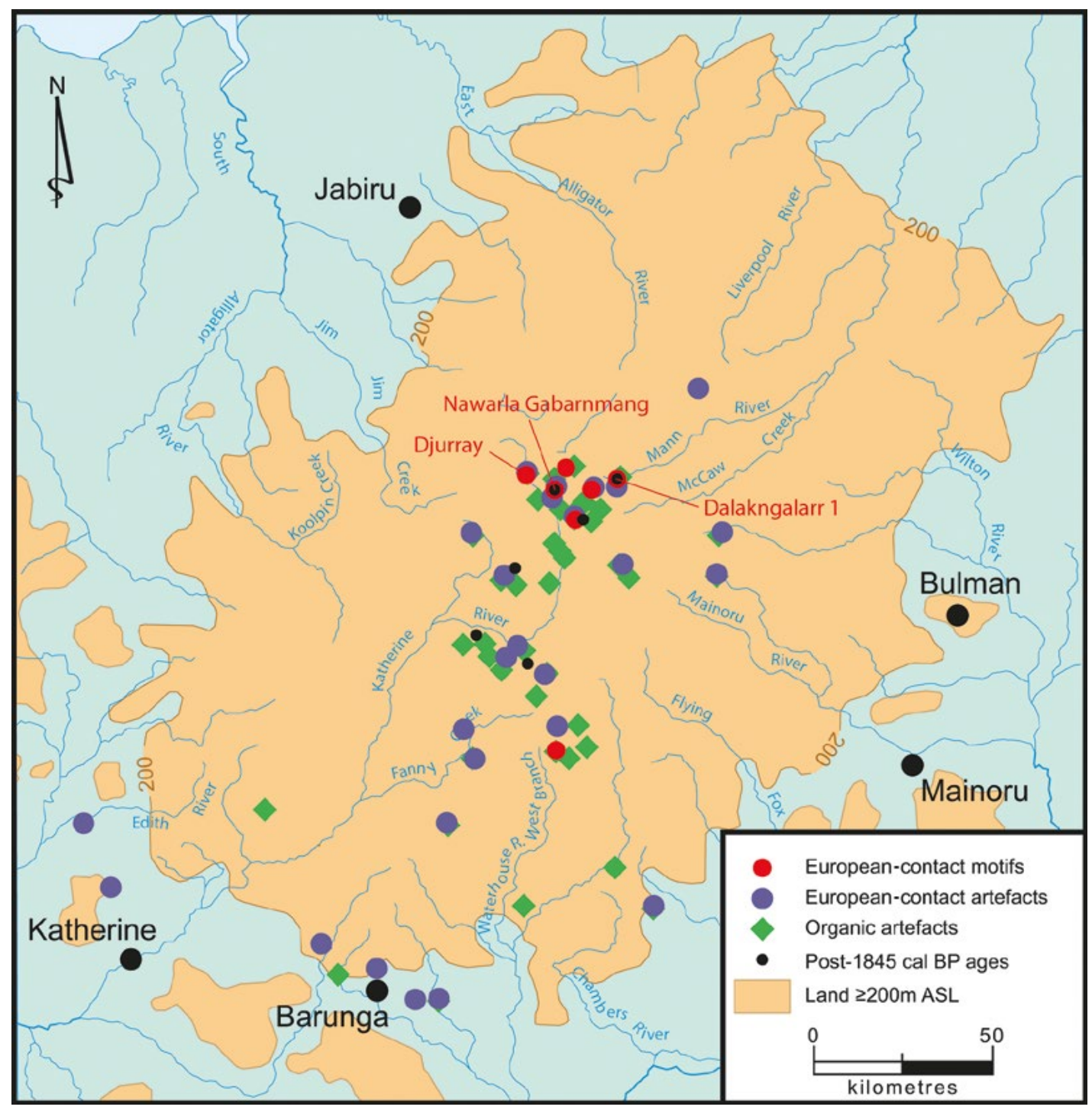

Figure 9.26 Distribution of European-contact period and organic artefacts in Jawoyn lands.

Source: Kara Rasmanis. 


\section{Discussion}

To date, 1079 rock art sites have been recorded from 127 site complexes in Jawoyn lands (including the plateau and surrounding uplands). Of these, only the seven reported here ( 0.6 per cent of sites) contain European-contact motifs of a kind discussed in this chapter (Figure 9.2). While a total survey of Jawoyn rock art sites is far from complete - we estimate that Jawoyn lands probably contain well over 1000 site complexes - the spatial patterning of European-contact imagery and portable items of material culture are based on extensive surveys covering the length and width of Jawoyn lands, and are thus considered to be representative of the region as a whole. In the Wellington Range $150 \mathrm{~km}$ to the north of Jawoyn lands and $30 \mathrm{~km}$ from the coast, paintings of boats account for 50 per cent of the non-Aboriginal-contact images (May et al. 2013:48), but paintings of European-contact objects occur in only 5 per cent of a sample of c. 150 sites (May et al. 2010:63, Figure 12). Hence, even in areas with close interactions with several waves of non-Aboriginal people (e.g. Macassan, European), contact motifs identifiably depicting contact events, personages and themes do not feature prominently in the rock art. The considerably lower proportion of contact motifs within Jawoyn lands is not surprising, given the relative paucity of interactions between Jawoyn people and outsiders over the period from 1845 to the turn of the 19th century and even later. Consequently, the dearth of contact motifs in Jawoyn lands can be directly attributed to a paucity of direct interactions with outsiders and the relatively minor direct intervention intruders had on traditional Jawoyn life during this period prior to depopulation of the Arnhem Land plateau (the devastating effects of introduced diseases such as yaws and smallpox notwithstanding).

Our work has found that European-contact motifs appear to be clustered in two general locations of the plateau in Jawoyn lands: six sites on the upper reaches of the Katherine River, and one site on the upper Waterhouse River (Figure 9.2). All but two are within large and welldecorated rockshelters (Table 9.7). The exceptional two, ARN-019/M and ARN-103/1, each contains a single image of what appear to be European men; indeed, they are the only locations where Europeans appear other than on depictions of boats. The images in the Katherine River headwaters can be subdivided on subject and stylistic grounds into three groups:

1. The standing figure at ARN-107/3 (Figure 9.7) and the figures on the large boat painting at ARN-088/6 (Boat A) (Figure 9.3) $17 \mathrm{~km}$ to the northwest, all of which share similar pigment colour, headwear (broad-brimmed European style hat), paint application (thickness of line work) and the body proportions of the figures.

2. The human figure painted in white at ARN-019/M (Figure 9.8), and the mounted red figure at ARN-087/1 (Figure 9.12), which both wear similar headwear (pith-helmets?) and, hence, probably relate to a similar period of time (or perhaps even to the same person or event).

3. The singular large polychrome horse motif at ARN-074/A (Figure 9.9).

Table 9.7 Sites with European-contact imagery on the plateau in Jawoyn lands.

\begin{tabular}{|l|l|l|l|l|}
\hline Site & \# of paintings & Shelter size: width $\times$ depth $\times$ height $(\mathbf{m})$ & Contact paintings & River catchment \\
\hline ARN-088/6 & 320 & $23 \times 8 \times 6$ & Boats $(7)$ & Katherine R. \\
\hline ARN-107/3 & 11 & $5 \times 2 \times 2$ & Man + top hat & Katherine R. \\
\hline ARN-019/M & 25 & $8 \times 2 \times 2$ & Man + rifle & Katherine R. \\
\hline ARN-074/A & $>800$ & $25 \times 15 \times 2$ & Horse & Katherine R. \\
\hline ARN-087/1 & 730 & $70 \times 4 \times 4$ & Horse + rider & Katherine R. \\
\hline ARN-082/1 & 350 & $14 \times 9 \times 2$ & Hatchets $(2)$ & Katherine R. \\
\hline ARN-031/1 & 344 & $28 \times 3 \times 4$ & Bullock & Waterhouse $R$. \\
\hline
\end{tabular}

Source: Authors' data. 
The images at ARN-087/1 (Figure 9.12) and ARN-074/A (Figure 9.9) are stylistically different from both each other and all other contact images within Jawoyn lands. The horse representations at these two sites are in very different styles and sizes. As the portrayal of the ARN-087/1 horse is truer to the active use of horses by people (e.g. presence of rider, reins) than is that of ARN074/A, the ARN-087/1 artist may have had better knowledge of horses than did the artist at ARN-074/A. The larger ARN-074/A horse may have been, therefore, painted following a first or relatively unfamiliar sighting of the animal. The subsequent superimpositioning of the large horse by an array of other motifs at this site also suggests that, with time, the original impact of the animal as a novel encounter diminished. On the other hand, the ARN-087/1 horse-andrider is both smaller in size and located in a more secluded position (where it could only be seen by one person at a time). Given the above factors, the ARN-087/1 horse-and-rider figure was arguably painted some time later than the ARN-074/A horse. The bullock with bell at ARN-031/1 (Figure 9.13) also shows good anatomical details, indicating first-hand knowledge of the animal; it was thus probably painted by someone who was already at least reasonably well acquainted with the animal, and possibly by someone who had themselves worked with cattle. If so, an early 20 th-century age is suggested for its creation, an interpretation consistent with the painting's excellent state of preservation.

Each of the European-contact paintings of animals within Jawoyn lands has a very different appearance. While these differences may reflect the artists' diverse attitudes, the varying states of preservation of the images coupled with the arguments made above suggest a progressive development of Jawoyn observation from an initial high impact of the unknown, to greater familiarity with the animals over time (Figure 9.27).

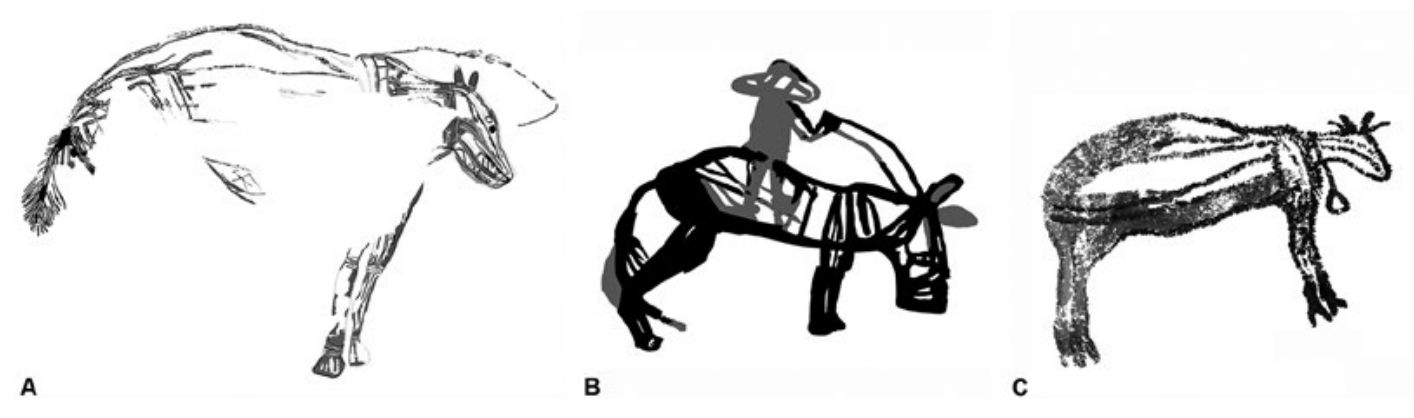

Figure 9.27 Proposed chronological sequence of introduced fauna (horse, cattle) motifs in Jawoyn lands. A: Early. B: Intermediate. C: Late.

Source: Robert Gunn.

Following the depopulation of the plateau in 1942, it appears that little, if any, rock art was produced in the Jawoyn lands of the Arnhem Land plateau, as use of rockshelters closer to newly established settlements seem to have replaced the more distant art shelters (see also Arndt 1962:169-170). Evidence in the form of a range of portable artefacts (e.g. suitcase and cat's-eye marble; Figures 9.18 and 9.19) indicates that Jawoyn and other Aboriginal peoples crossing the plateau probably continued to use rockshelters as camping places between 1910 and the closing of the Maranboy tin mines in the early 1950s. While it is possible that a small amount of rock art was produced in Jawoyn sites on the plateau during post-1940 crossings, no such images have yet been identified (Smith 1994:233, 235). When Wamud Nadjamerrek walked over the Arnhem Land plateau with his family in the 1930s, they camped at the spectacular rock art site of Nawarla Gabarnmang (ARN-074/A). On his return visit in 2008, he remembered the well-decorated ceiling and thought that there had been no additional rock art images added to the panels since his earlier visit (Wamud Nadjamerrek, pers. comm. to Ray Whear 2008). As this is one of the most decorated and, based on the size of the utilised floor space and density of surface cultural 
materials, one of the most visited camping shelters on the plateau in Jawoyn lands, it is likely that the shelter would have traces of any major recent period of rock art production occurring on the plateau following Nadjamerrek's visit. Consequently, an absence of any additional, recent artwork at Nawarla Gabarnmang is consistent with the notion that rock art production did not flourish on the plateau in Jawoyn lands in the period after 1930.

\section{Conclusion}

The Jawoyn lands of the Arnhem Land plateau were widely occupied during the early Europeancontact period, but effectively depopulated from the 1940s onwards. Here, rock art production appears to have continued until around 1930 (Gunn et al. 2012a). Despite this, nowhere in Jawoyn lands are paintings of European objects, people or events commonly found, and the few that have been found occur close to the routes taken by Leichhardt and Lindsay. Arguably, all of these European-contact motifs date to the early period of European contact (after 1845 AD) and, hence, these paintings depict very early, perhaps even first-contact encounters. The implication is that while Indigenous artists continued to paint on the plateau, it is not European themes that directed their artistic attention, nor Europeans or other outsiders, but rather everyday concerns that featured in established cosmologies that continued to guide how they viewed the world to operate. The exception appears to have been the early contact period, a time that necessitated the incorporation of foreigners into a pre-established world order. The key reference points for artistic works continued to be ancestral connections articulating the Spirit-Beings and stories that gave and continued to give shape to Country. Europeans had become a new presence, a powerful one that began to change Indigenous lives, but they did not feature significantly in the existential workings of the world, and so did not feature in the artworks that depicted those liminal spaces between the materially embodied living and the numinous. It is later, with the dislocation of people from the plateau during World War II, that the act of painting largely ceased, although Jawoyn individuals and groups visiting places on the plateau after that time continued to relate to places and 'artworks' as living presences of emplaced Spirit-Beings, sometimes deceased ancestors, sometimes not, but always mediated by Dreaming cosmologies.

\section{Acknowledgements}

This study was undertaken as part of the Jawoyn Rock Art and Heritage Programme (JRAHP), and was fully supported by Margaret Katherine, senior Traditional Owner of the Buyhmi clan estate, and the Board of the Jawoyn Association, Katherine. Our thanks also go to the many other Jawoyn people who assisted in this project: Larry Atkinson, Lily Bennett, Peter Bolgay, Mildred Brennnan-Kuawangai, Nell Brown, Nikabini Dalak, Dudley Lawrence, Peter Manaburra, Ken Murray, Wamud Nadjamerrek, Sybil Ranch, Ester Runyu, Jimmy Wesan, Phyllis Wiynjorrotj, Hitler Wood and Lily Wuy Wuy. Leigh Douglas, David Lee, Charlotte Anderson, Chris Urwin and Britt Wilson assisted with the fieldwork, and Chris Morgan flew us out to the majority of the sites recorded. Thanks to Paul Clark (maritime historian, Museum and Art Galleries of the Northern Territory), David Steinberg (maritime archaeologist, Northern Territory Heritage Branch) and Adrian Horridge (historian) for identifying and commenting on boat images. Thanks also to Nadia Iacono for identifying the site ARN-082/1 glass bead, Kara Rasmanis (Monash University) for drafting Figures 9.1, 9.2, 9.17 and 9.26, and Steve Morton (Scientific Imaging Services, Monash University) for the photographs in Figures 9.23 and 9.25. The JRAHP was funded by the Jawoyn Association and grants from the federal government's Indigenous Heritage Programme. Additional funding was provided under the George Chaloupka Fellowship, an initiative of the Museum and Art Gallery of the Northern Territory Foundation, sponsored 
by Energy Resources of Australia (ERA) Ltd, of which both RG (2009) and DJ (2012) were recipients. We thank the Australian Research Council for Linkage grant LP110200927 and Discovery Outstanding Research Award (DORA) Fellowship (to BD) DP130102514.

\section{References}

Arndt, W. 1962. The interpretation of Delamere lightning paintings and rock engravings. Oceania 32:163-177. doi.org/10.1002/j.1834-4461.1962.tb01759.x

Australian Dictionary of Biography 1974. McKinlay, John (1819-1872). Australian Dictionary of Biography. National Centre of Biography, The Australian National University, Canberra. adb.anu. edu.au/biography/mckinlay-john-4113/text6577 (accessed 31 March 2017).

Chalmin E., M. Menu and C. Vignaud 2003. Analysis of rock art painting and technology of Palaeolithic painters. Measurement Science and Technology 14:1590-1597. doi.org/10.1088/0957$0233 / 14 / 9 / 310$

Chaloupka, G. 1993. Journey in Time: The World's Longest Continuing Art Tradition. Reed, Chatswood.

Cooke, P.M. 2009. Buffalo and tin, baki and Jesus: The creation of a modern wilderness. In J. RussellSmith, P. Whitehead and P. Cooke (eds), Culture, Ecology and Economy of Fire Management in North Australian Savannas: Rekindling the Wurrk Tradition, pp. 69-83. CSIRO Ebooks, Canberra.

David, B., J.-M. Geneste, R.L. Whear, J.-J. Delannoy, M. Katherine, R.G. Gunn, C. Clarkson, H. Plisson, P. Lee, F. Petchey, C. Rowe, B. Barker, L. Lamb, W. Miller, S. Hoerle, D. James, E. Boche, K. Aplin, I.J. McNiven, T. Richards, A. Fairbairn and J. Matthews 2011. Nawarla Gabarnmang, a 45,185 $\pm 910 \mathrm{cal}$ BP site in Jawoyn Country, southwest Arnhem Land Plateau. Australian Archaeology 73:73-77.

Davis, J. 1863. Tracks of McKinlay and Party Across Australia. Westgarth, London.

Edwards, R. 1979. Australian Aboriginal Art: The Art of the Alligators Rivers Region, Northern Territory. Australian Institute of Aboriginal Studies, Canberra.

Flood, J. 1997. Rock Art of the Dreamtime. Angus and Robertson, Sydney.

Geneste, J.-M., B. David, H. Plisson, J.-J. Delannoy and F. Petchey 2012. The origins of ground-edge axes: New findings from Nawarla Gabarnmang, Arnhem Land (Australia) and global implications for the evolution of fully modern humans. Cambridge Archaeological Journal 22:1-17. doi.org/10.1017/ S0959774312000017

Gunn, R.G. 1992. Bulajang: A reappraisal of the archaeology of an Aboriginal cult. In J. McDonald and I.P. Haskovec (eds), State of the Art, pp. 174-194. Occasional AURA Publication 6. Australian Rock Art Research Association, Melbourne.

Gunn, R.G. and R.L. Whear 2007. The Jawoyn Rock Art and Heritage project. Rock Art Research 24:5-20.

Gunn, R.G. and R.L. Whear 2008. A singular beeswax representation of Namarrkon, the Lightning Man, from Western Arnhem Land. Australian Aboriginal Studies 2008(2):54-69.

Gunn, R.G., R.L. Whear and L.C. Douglas 2010. A dingo burial from the Arnhem Land plateau. Australian Archaeology 71:11-16. doi.org/10.1080/03122417.2010.11689380

Gunn, R.G., R.L. Whear and L.C. Douglas 2012a. Dating the present at Nawarla Gabarnmang: Time and function in the art of a major Jawoyn rock art and occupation site in western Arnhem Land. Australian Archaeology 75:55-65. doi.org/10.1080/03122417.2012.11681950 
Gunn, R.G., R.L. Whear and L.C. Douglas 2012b. A second recent canine burial from the Arnhem Land plateau. Australian Archaeology 74:103-105. doi.org/10.1080/03122417.2012.11681939

Hardman, W. 1865. Journal of Mr Stuart's Successful Expedition across the Continent of Australia from December 1861 to December 1862. eBooks@Adelaide, University of Adelaide Library, Adelaide. ebooks. adelaide.edu.au/s/stuart/john_mcdouall/journals/chapter6.html\#chapter6 (accessed 3 April 2013).

Hua, Q., M. Barbetti and A.Z. Rakowski 2013. Atmospheric radiocarbon for the period 1950-2010. Radiocarbon 55(4):2059-2072. doi.org/10.2458/azu_js_rc.v55i2.16177

Keen, I. 1980. The Alligator Rivers Aborigines: Retrospect and prospect. In R. Jones (ed.), Northern Australia: Options and Implications, pp. 171-186. Research School of Pacific Studies, The Australian National University, Canberra.

Leichhardt, L. 1847. Journal of an Overland Expedition in Australia, from Moreton Bay to Port Essington, a Distance of Upwards of 3000 Miles, during the Years 1844-1845. T. and W. Boone, London.

Levitus, R. 1995. Social history since colonisation. In T. Press, D. Lea, A. Webb and A. Graham (eds), Kakadu: Natural and Cultural Heritage Management, pp. 64-93. Australian Nature Conservation Agency, Darwin.

Lewis, D. 1988. The Rock Paintings of Arnhem Land, Australia. BAR International Series 415. British Archaeological Reports, Oxford.

Lindsay, D. 1884. Mr D. Lindsay's Exploration through Arnheim's Land. South Australian Government Printer, Adelaide.

MacKnight, C.C. 1972. Macassans and Aborigines. Oceania. 42:283-321. doi.org/10.1002/j.18344461.1972.tb01183.x

MacKnight, C.C. 1986. Macassans and the Aboriginal past. Archaeology in Oceania 21:69-75. doi.org/10.1002/j.1834-4453.1986.tb00126.x

McDonald, J. 2008. Dreamtime Superhighway: Sydney Basin Rock Art and Prehistoric Information Exchange. Terra Australis 27. ANU E Press, Canberra.

May, S.K., P.S.C. Taçon, A. Paterson and M. Travers 2013. The world from Malarrak: Depictions of Southeast Asian and European subjects in rock art from the Wellington Range, Australia. Australian Aboriginal Studies 2013(1):45-56.

May, S.K., P.S.C. Taçon, D. Wesley and M. Travers 2010. Painting history: Indigenous observations and depictions of the 'Other' in northwestern Arnhem Land, Australia. Australian Archaeology 71:57-65. doi.org/10.1080/03122417.2010.11689384

Merlan, F. 1998. Caging the Rainbow: Places, Politics and Aborigines in a North Australian Town. University of Hawaii Press, Honolulu.

Merlan, F. and P. Jacq 2005. Jawoyn-English Dictionary and English Finder List. Diwurruwurru-jaru Aboriginal Corporation, Katherine.

Mitchell, S. 1994. Culture contact and Indigenous Economies on the Coburg Peninsula, Northwestern Arnhem Land. Unpublished PhD thesis. Northern Territory University, Darwin.

Mountford, C.P. (ed.) 1956. Records of the American-Australian Scientific Expedition to Arnhem Land, Vol. 1: Art, Myth and Symbolism. Melbourne University Press, Melbourne.

Mulvaney, D.J. 1975. The Prehistory of Australia. Penguin, Ringwood. 
Murdoch, L. 2009. Lost and found: Leichhardt was here. Sydney Morning Herald 7 March 2009:1.

Nadjamerrek, L.B., K. Munro and Museum of Contemporary Art 2010. Bardayal 'Lofty' Nadjamerrek $A O$. Museum of Contemporary Art, Sydney.

Ouzman, S. 2003. Indigenous images of a colonial exotic: Imaginings from Bushmen southern Africa. Before Farming 1(6):239-256. doi.org/10.3828/bfarm.2003.1.6

Reimer, P.J., E. Bard, A. Bayliss, J.W. Beck, P.G. Blackwell, C. Bronk Ramsey, C.E. Buck, H. Cheng, R.L. Edwards, M. Friedrich, P.M. Grootes, T.P. Guilderson, H. Haflidason, I. Hajdas, C. Hatté, T.J. Heaton, D.L. Hoffmann, A.G. Hogg, K.A. Hughen, K.F. Kaiser, B. Kromer, S.W. Manning, M. Niu, R.W. Reimer, D.A. Richards, E.M. Scott, J.R. Southon, R.A. Staff, C.S.M. Turney and J. van der Plicht 2013. IntCal13 and Marine13 radiocarbon age calibration curves, 0-50 000 years cal BP. Radiocarbon 55 (4):1869-1887. doi.org/10.2458/azu_js_rc.55.16947

Rose, D.B. 1992. Dingo Makes Us Human: Land and Life in an Australian Aboriginal Culture. Cambridge University Press, Cambridge.

Smith, C. 1994. Situating Style: An Ethnoarchaeological Study of Social and Material Context in an Australian Aboriginal Artistic System. Unpublished PhD thesis. University of New England, Armidale.

Taçon, P.S.C., S.K. May, S.J. Fallon, M. Travers, D. Wesley and R. Lamilami 2010. A minimum age for early depictions of Southeast Asian praus in the rock art of Arnhem Land, Northern Territory. Australian Archaeology 71:1-10. doi.org/10.1080/03122417.2010.11689379

Thompson, D. 1975. Bindibu Country. Nelson, Melbourne.

Wesley, D. 2013. Firearms in rock art of Arnhem Land, Northern Territory, Australia. Rock Art Research $30: 235-247$.

Wesley, D. and M. Litster 2015. 'Small, individually nondescript and easily overlooked': Contact beads from northwest Arnhem Land in an Indigenous-Macassan-European hybrid economy. Australian Archaeology 80:1-16. doi.org/10.1080/03122417.2015.11682040

Wesley, D., S. O'Connor, S and J. Fenner 2016. Re-evaluating the timing of the Indonesian trepang industry in north-west Arnhem Land: Chronological investigations at Malara (Anuru Bay A). Archaeology in Oceania 51(3):169-195.

Wilson, M., M. Spriggs and E. Lawson 2001. Dating the rock art of Vanuatu: AMS radiocarbon determinations from abandoned mud-wasp nests and charcoal pigment found in superimposition. Rock Art Research, 18(1):24-31. 
This text is taken from The Archaeology of Rock Art in Western Arnhem Land, Australia, edited by Bruno David, Paul Taçon, Jean-Jacques Delannoy and Jean-Michel Geneste, published 2017 by ANU Press, The Australian National University, Canberra, Australia. 